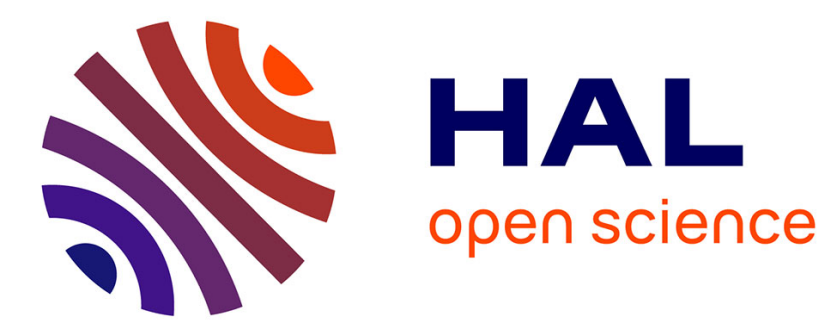

\title{
The Complex Vertical Motion of Intraplate Oceanic Islands Assessed in Santiago Island, Cape Verde
}

F. o. O Marques, A. Hildenbrand, H. Zeyen, C. Cunha, S. s. S Victória

\section{To cite this version:}

F. o. O Marques, A. Hildenbrand, H. Zeyen, C. Cunha, S. s. S Victória. The Complex Vertical Motion of Intraplate Oceanic Islands Assessed in Santiago Island, Cape Verde. Geochemistry, Geophysics, Geosystems, 2020, 21 (3), 10.1029/2019GC008754 . hal-03004908

\section{HAL Id: hal-03004908 https://hal.science/hal-03004908}

Submitted on 13 Nov 2020

HAL is a multi-disciplinary open access archive for the deposit and dissemination of scientific research documents, whether they are published or not. The documents may come from teaching and research institutions in France or abroad, or from public or private research centers.
L'archive ouverte pluridisciplinaire HAL, est destinée au dépôt et à la diffusion de documents scientifiques de niveau recherche, publiés ou non, émanant des établissements d'enseignement et de recherche français ou étrangers, des laboratoires publics ou privés. 
This is the peer reviewed version of the following article:

Marques, F. O., Hildenbrand, A., Zeyen, H., Cunha, C., \& Victória, S. S. (2020). The complex vertical motion of intraplate oceanic islands assessed in Santiago Island, Cape Verde. Geochemistry, Geophysics, Geosystems, 21, e2019GC008754. https://doi.org/10.1029/2019GC008754, which has been published in final form at https://doi.org/10.1029/2019GC008754.

This article may be used for non-commercial purposes in accordance with Wiley Terms and Conditions for Use of Self-Archived Versions 


\title{
The complex vertical motion of intraplate oceanic islands
} assessed in Santiago Island, Cape Verde

\author{
F.O. Marques ${ }^{a^{*}}$, A. Hildenbrand ${ }^{b}$, H. Zeyen ${ }^{b}$, C. Cunha ${ }^{c}$, S.S. Victória ${ }^{d}$ \\ ${ }^{a}$ Universidade de Lisboa, Lisboa, Portugal \\ ${ }^{b}$ GEOPS, Université Paris-Sud, CNRS, Université Paris-Saclay, 91405 Orsay, France \\ ${ }^{c}$ Instituto Politécnico de Coimbra, Escola Superior Agrária, Coimbra, Portugal \\ ${ }^{d}$ Universidade de Cabo Verde, Praia, Cabo Verde \\ *Corresponding author. Tel.: +351 217500000; Fax: +351 217500064 \\ E-mail address: fomarques@fc.ul.pt
}

1

\section{Abstract}

3 Dated paleo-sea level markers and eustatic sea level changes are necessary but not sufficient information to calculate vertical motion rates on oceanic islands. Therefore, we use a procedure in which we work progressively back in time to incorporate the more recent vertical motion rates implied by the youngest paleoshorelines into the vertical motion history of all older shorelines.

Specifically, we calculate the time-averaged vertical motion rates required to explain the presentday elevations of the dated sequence of paleoshorelines on Santiago volcanic island (Cape Verde).

We thus obtain a vertical motion history consisting of time-averaged vertical motion rates spanning the five intervening periods between paleoshoreline formation and the present day: (1) 5.06 to 3.29 $\mathrm{Ma}$ - seamount growth or island subsidence because all the rocks in this period are submarine; (2) fast uplift (ca. $0.96 \mathrm{~mm} / \mathrm{a}$ ) from 3.29 to $2.87 \mathrm{Ma}$, mostly responsible for putting submarine lavas 
23 currently close to $410 \mathrm{~m}$ altitude; (3) relatively fast subsidence (ca. $-0.11 \mathrm{~mm} / \mathrm{a}$ ) between 2.87 and

$242.18 \mathrm{Ma}$; (4) stagnation from 2.18 to $0.811 \mathrm{Ma}$; (5) relatively fast uplift (ca. $0.14 \mathrm{~mm} / \mathrm{a}$ ) between

$25 \quad 0.811$ and $0 \mathrm{Ma}$. We numerically tested top-down (volcanic loading) and bottom-up (lithosphere

26 thinning, underplating and mantle plume) mechanisms to explain the inferred vertical movements,

27 and we conclude that volcanic loading and crustal underplating are capable of producing the

28 observed subsidence and uplift, respectively.

\section{Plain Language Summary}

Oceanic volcanic islands experience vertical movements during their lifetime, which can be

32

33

34

35

36

37

38 the consequence of several mechanisms like bending of the lithosphere due to the island's weight (subsidence), or horizontal intrusion of magma below the volcanic edifice (uplift). In order to discriminate among the possible mechanisms, we must correctly estimate the successive vertical displacements and motion rates. We account for eustatic sea level change and use dated paleoshorelines, working progressively back in time to incorporate the more recent vertical motion rates implied by the youngest paleoshorelines into the vertical motion history of all older shorelines, to obtain a step-by-step vertical motion history:: (1) 5.06 to $3.29 \mathrm{Ma}$ - seamount growth or island subsidence because all the rocks in this period of time are submarine; (2) fast uplift (ca. $0.96 \mathrm{~mm} / \mathrm{a}$ ) from 3.29 to $2.87 \mathrm{Ma}$ mostly responsible for putting submarine lavas currently close to $410 \mathrm{~m}$ altitude; (3) relatively fast subsidence (ca. $-0.11 \mathrm{~mm} / \mathrm{a}$ ) between 2.87 and $2.18 \mathrm{Ma}$; (4) stagnation from 2.18 to $0.811 \mathrm{Ma}$; (5) relatively fast uplift (ca. $0.14 \mathrm{~mm} / \mathrm{a}$ ) between 0.811 and 0 Ma. From analytical and numerical modeling we conclude that volcanic loading and crustal underplating are likely mechanisms to explain the observed vertical displacements. 
46 Keywords: uplift and subsidence rates of oceanic islands; vertical displacement in Santiago Island,

47 Cape Verde; sea level changes; paleoshorelines; passage zones; topography response to isostasy

\section{Introduction}

The vertical motion of oceanic islands records the interactions between volcanic load,

51 mantle flow and lithospheric reaction to both. An important step toward understanding the mechanisms responsible for the vertical motions in volcanic ocean islands is therefore the estimation of rates of vertical displacement. When one finds a submarine lava flow currently at 400 $\mathrm{m}$ altitude on an island, it means that the island was uplifted, because no specific eustatic sea level change can, by itself, explain such position. The problem is that we do not know when and how the uplift took place. As an end member, one can assume that the uplift was linear from the time of

57 formation of the rock to present day (e.g. Ramalho et al., 2010a, c). If the rock is 4 Ma old, then $58400000 \mathrm{~mm}$ divided by $4,000,000$ a equals $0.1 \mathrm{~mm} / \mathrm{a}$. But this assumption can be grossly wrong if geological evidence indicates that the uplift is much younger or in a much shorter period of time. If

60

61

62

63

64

65

66

67 the rock is $4 \mathrm{Ma}$ but uplift occurred only in the last $1 \mathrm{Ma}$, then the uplift rate is $0.4 \mathrm{~mm} / \mathrm{a}$, i.e. 4 times greater than the linear estimate. If uplift occurred at $4 \mathrm{Ma}$ but over a short period of time of 0.4 Ma, then the uplift rate would be $1 \mathrm{~mm} / \mathrm{a}$, i.e. one order of magnitude greater than the linear estimate. Finally, we also do not know how the submarine rock currently observed at $400 \mathrm{~m}$ altitude got there: was it by jerks? Or was it intercalated with periods of subsidence and/or quiescence? The unravelling of these problems is the main objective of this work. In the end, we use analytical solutions and numerical modeling to find likely mechanisms capable of explaining such vertical displacements, based on the case of Santiago Island in Cape Verde.

The calculation of vertical motion rates in an oceanic island depends critically on two 
69 parameters: position of a paleosealevel marker at a given time. Therefore, determining the current

70 elevation as well as the age and depth of formation of a paleoshoreline indicator are required to

71 calculate vertical motion rates. To accomplish this fundamental objective, we looked for field

72 evidence that allows us to determine the position of a given rock in space and time: lavas in a

73 passage zone (transition from subaerial to submarine flow defining the paleoshoreline), preferably

74 with in situ shallow water fossils, and which are most suitable for K-Ar dating.

75 Paleoshorelines record relative sea level, therefore their elevation above or below current

76 sea level results from changes in both land and/or glacio-eustatic sea level, which has changed over

77 time (e.g. Bintanja et al., 2005; De Boer et al., 2010; Hansen et al., 2013; Miller et al., 2005, 2011).

78 Therefore, when analyzing vertical motions in a volcanic island, the eustatic variations of sea level

79 must be considered.

80

The use of paleoshorelines and glacio-eustatic sea level curves has been used in previous

81 works, as the methodology to assess an island's vertical motion rate (e.g. Cas and Wright, 1987;

82 Jones, 1969; Jones and Nelson, 1970; Porebski and Gradzinski, 1990; Ramalho et al., 2013). 


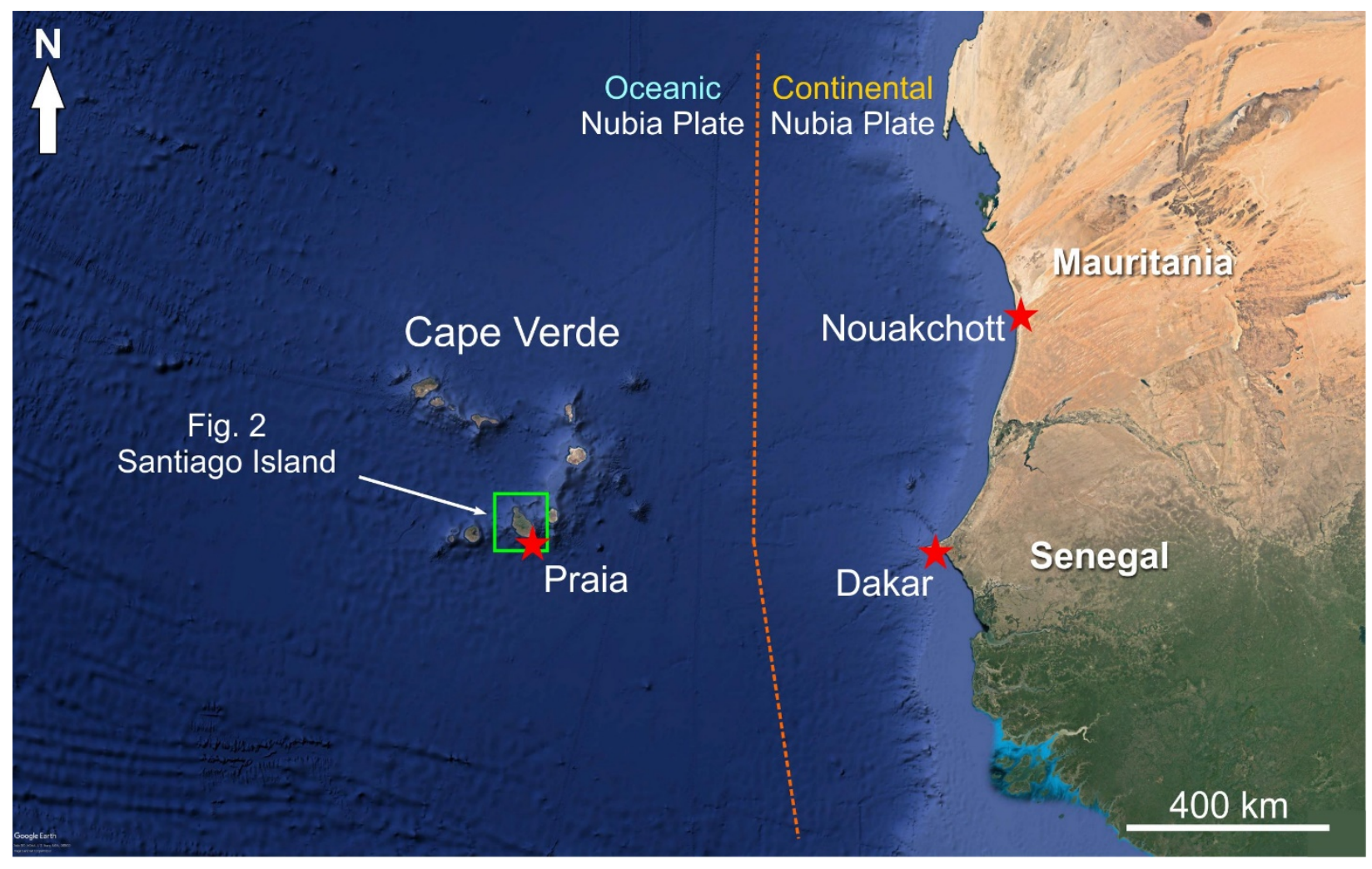

Figure 1. Annotated Google Earth image showing geographic location and tectonic setting of the Cape Verde archipelago.

The Cape Verde Archipelago comprises ten islands located about $700 \mathrm{~km}$ west of Dakar in Senegal (Fig. 1). They lie on Jurassic-Cretaceous seafloor, which is the basement above which the Cape Verde Rise and islands rise 2 to $8 \mathrm{~km}$, respectively. Santiago Island, the target of the study reported here, is one of the islands where evidence for large vertical motion can be found. Previous work (Ramalho et al. 2010a, c) deduced a linear relationship between the vertical displacement and age of paleoshorelines on the island, implying a constant uplift rate over the past $\sim 4 \mathrm{Ma}$. Such a relation seems incompatible with the isostatic response of the lithosphere to the complex evolution of an ocean volcanic island, which encompasses major episodes of construction and erosion/destruction (top-down forcing) as well as mantle/crustal processes like crustal underplating (bottom-up forcing). 

at time intervals between paleoshoreline formation, and discuss possible mechanisms responsible

99 for vertical displacement. To accomplish these objectives, we used the following methodology:

100 analysis of aerial imagery for geomorphological and geological interpretation; fieldwork to 101 recognize the major unconformities and volcanic units, to unravel the geometry and position of

102 main volcanoes, and to find the critical paleodepth markers (paleoshorelines); sampling for high103 precision K-Ar dating, used to calibrate the volcanic stratigraphy and to obtain the ages of the 104 critical paleodepth markers.

105

\section{Geological setting}

107

Santiago is the largest of the ten inhabited islands in Cape Verde. It is elongated NNW-SSE,

108 it shows rugged topography with large (km wide) and deep (up to $1 \mathrm{~km}$ ) canyons (Fig. 2A), and

109 peaks at $1394 \mathrm{~m}$ at Pico da Antónia, in the center-south of the island. The northern two thirds of the

110 island are cut by deep valleys, but, in places (e.g. west of Assomada village, center of the island),

111 rugged paleotopographies can still be recognized comprising major unconformities filled with

112 younger lavas (Fig. 3). 


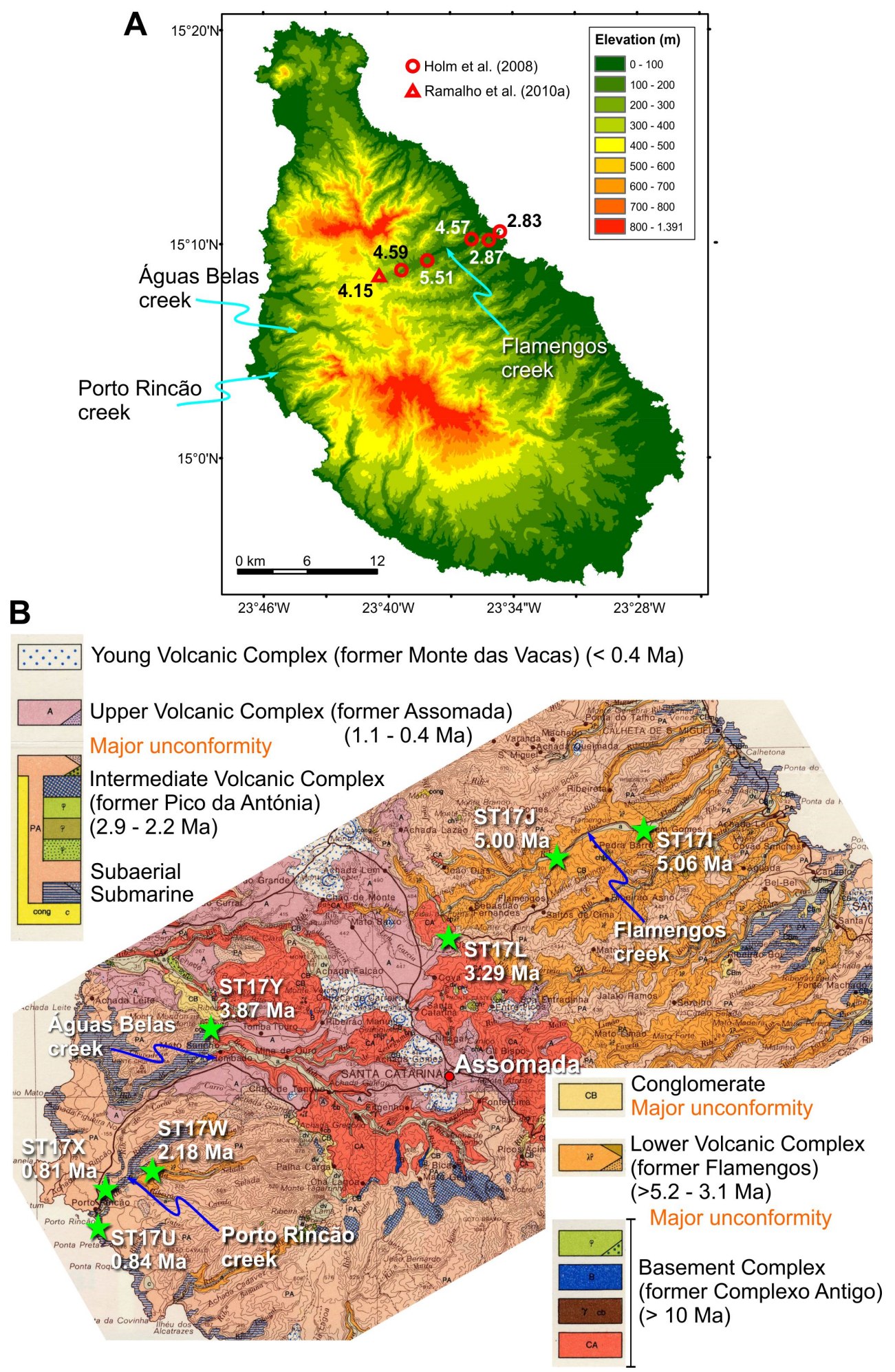

Figure 2. A-digital elevation model showing the main morphological features of Santiago, and 116 relevant ages (in Ma) from previous studies. B - geological map of study region, (Serralheiro, 117 1976) with simplified volcanic stratigraphy, sample locations (green stars), sample references, and ages obtained in the present work. 
The volcanic stratigraphy of the island, based on unconformity bounded stratigraphic units, 120 is well established (Serralheiro, 1976). (Fig. 2). However, the geological map shows important 121 inconsistencies, as suggested previously by Holm et al. (2008) and indicated here for, at least, the 122 Porto Rincão and Águas Belas creeks. The volcanic stratigraphy of the island comprises five main 123 volcanic complexes (Serralheiro (1976), the local names of which have no meaning to the common 124 reader. Therefore, we introduce here more intuitive names for the different volcanic complexes, 125 which are from bottom to top (Fig. 2B):

126 (1) the Basement Complex (former Complexo Antigo of Serralheiro, 1976) - deeply eroded unit 127 mostly composed of intensely altered igneous rocks pervasively intruded by dykes and small 128 pockets of plutonic rocks. The Basement Complex may represent an early submarine edifice 129 (Serralheiro, 1976), but its original setting (submarine or sub-aerial) is still disputed. Biotite 130 from a foidal gabbro, and biotite/phlogopite from carbonatites in the Basement Complex were dated at ca. $10 \mathrm{Ma}$ (Bernard-Griffiths et al., 1975), which can be regarded as the minimum age for the Basement Complex because the dated rocks occur high in this unit.

(2) Lower Volcanic Complex (former Flamengos Formation) - this unit lies on the Basement Complex through a major unconformity, and is, according to current knowledge, exclusively 137 thousand years around 4.6 Ma.

138 (3) Intermediate Volcanic Complex (former Pico da Antónia Formation) - this unit overlies the 139 Basement Complex and the Lower Volcanic Complex through a major unconformity, in places 140 with a thick conglomerate, and is composed of subaerial flows that pass into submarine flows 141 close to the current coast. This unit outcrops from current sea level to an altitude of c. $1394 \mathrm{~m}$ at 
Pico da Antónia, and was dated in the range 3.3 to $2.2 \mathrm{Ma}$ (Holm et al., 2008).

143

144

145

146

147

148

149

150

151

152

153

154

155

156

157

158

159

160

161

(4) Upper Volcanic Complex (former Assomada Formation) - this unit is mostly composed of thick subaerial lava flows unconformably overlying all previous units. The volcanic products of this unit fill valleys deeply carved in the Lower and Intermediate Volcanic Complexes, in places putting the Upper Volcanic Complex directly in contact with the Basement Complex (e.g. Águas Belas Creek). According to all previous work (e.g. Serralheiro, 1976; Holm et al., 2008; Ramalho et al., 2010a, c), the lava flows of this later volcanic period apparently did not reach the sea (no pillow lavas recognized in this unit), as can be confirmed on the geological map (Serralheiro, 1976).

(5) Young Volcanic Complex (former Monte das Vacas Formation of Serralheiro, 1976) - this unit is made of Strombolian cones lying unconformably on all previous units, and it represents the latest episode of volcanism. Holm et al. (2008) considered these two younger units (UVC and YVC) together as "late volcanism", for which they attributed an age between 1.1 and 0.7 Ma.

\section{Field data}

Field work carried out in the critical areas of the Flamengos (east Santiago), Porto Rincão and Águas Belas (west Santiago) creeks revealed the existence of major unconformities, which helped us better constrain the volcanic stratigraphy. We also found the critical outcrops comprising passage zones, locally with in situ shallow water fossils (mouth of the Porto Rincão Creek), with very fresh rock appropriate for reliable and precise dating by K-Ar. 

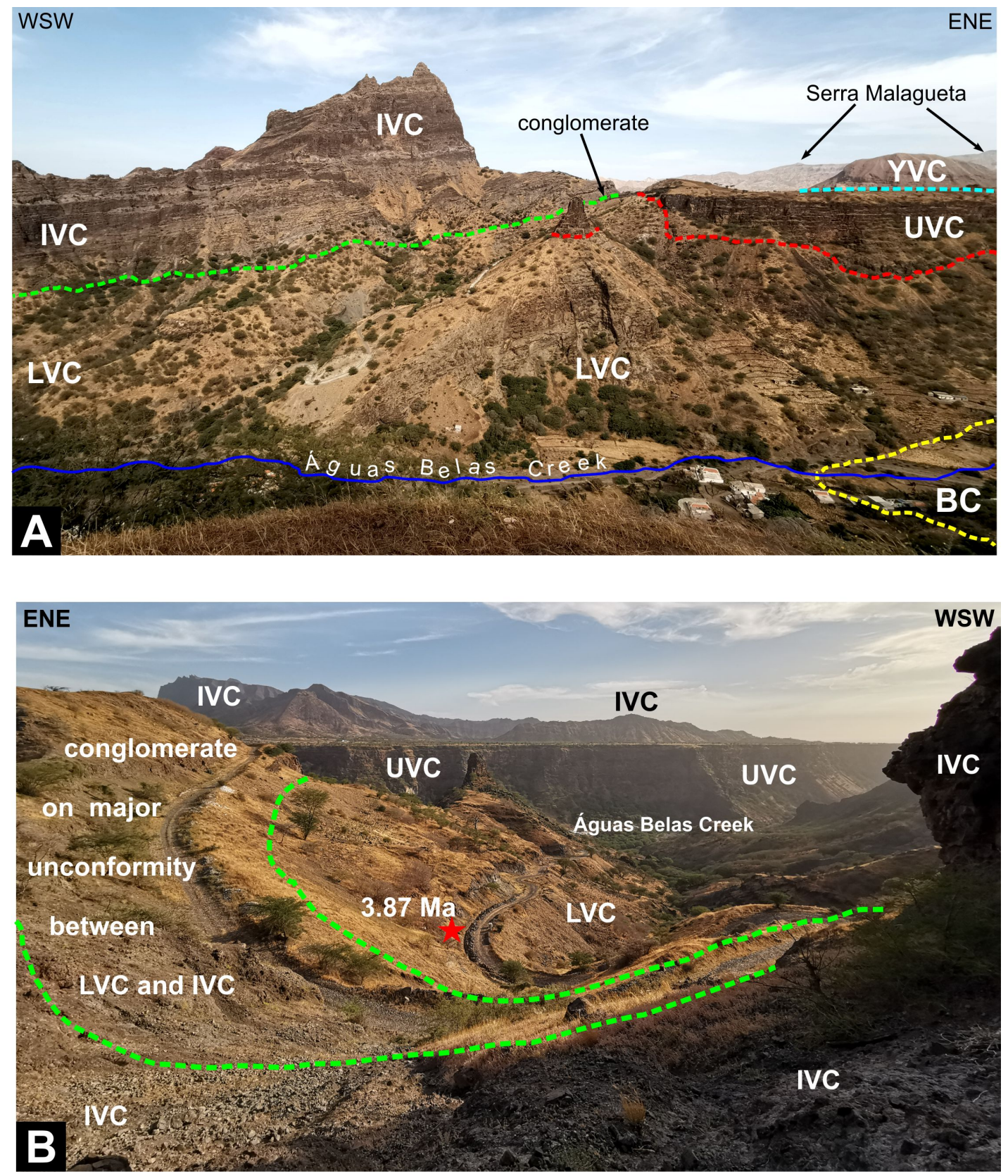

Figure 3. Annotated photographs taken to north (A) and south (B) of the Águas Belas creek with volcanic stratigraphy based on main unconformities and calibrated by $K$-Ar dating. In both images, especially in B, it is clear that the lava flows of the UVC fill deep valleys carved in both IVC and $L V C$, which stand higher than the UVC despite being older. From bottom to top: BC-Basement LVC-Lower Volcanic Complex (submarine flows) unconformably overlain by IVC (green dashed 169 line) and by UVC (red dashed line); IVC-Intermediate Volcanic Complex (subaerial in the image) 170 unconformably overlying the LVC through a thick conglomerate, and unconformably overlain by 171 UVC; UVC-Upper Volcanic Complex made of subaerial flows filling a rugged topography carved 172 in BC, LVC and IVC, and passing into submarine flows close to the coast (west, out of the image). 
The main geology in the deep Águas Belas valley (Fig. 3) shows a major unconformity, 174 filled with a very thick conglomerate, between the Intermediate Volcanic Complex and the 175 underlying Lower Volcanic Complex. This is not consistent with the geological map where the 176 underlying lavas are mapped as the submarine equivalent of the overlying Intermediate Volcanic 177 Complex.

178 The critical outcrops at the mouth of the Porto Rincão Creek show clear examples of 179 passage zones currently at ca. $43 \mathrm{~m}$ altitude (Supp. Fig. 1). Further upstream in the creek, we could 180 distinguish a different unit, still made of subaerial lavas passing into submarine, but with many 181 dykes cutting through the unit. The new ages confirmed that it is actually a different unit (cf. Fig. $1824)$.

In the Flamengos valley, east Santiago, opposite to the Águas Belas valley, we can observe 184 two different sequences of submarine lava flows: (1) at the mouth of the Flamengos Creek, a well 185 preserved passage zone, ca. $20 \mathrm{~m}$ above current sea level, dated by Holm et al. (2008) at ca. 2.85 186 Ma (their samples 121367 and 121371), so confirming the geological map of Serralheiro (1976); 187 (2) a very thick sequence (Lower Volcanic Complex, former Flamengos Formation) of gently east 188 dipping submarine lava flows and pyroclasts up to ca. $420 \mathrm{~m}$ altitude, where we can observe the 189 unconformable contact with the overlying Upper Volcanic Complex (former Assomada Formation). 190 We could not find a passage zone in this unit, neither here nor in the Águas Belas valley, so we just 191 collected the uppermost submarine rocks just below the conglomerates making up the major 192 unconformity. 
A

$E$
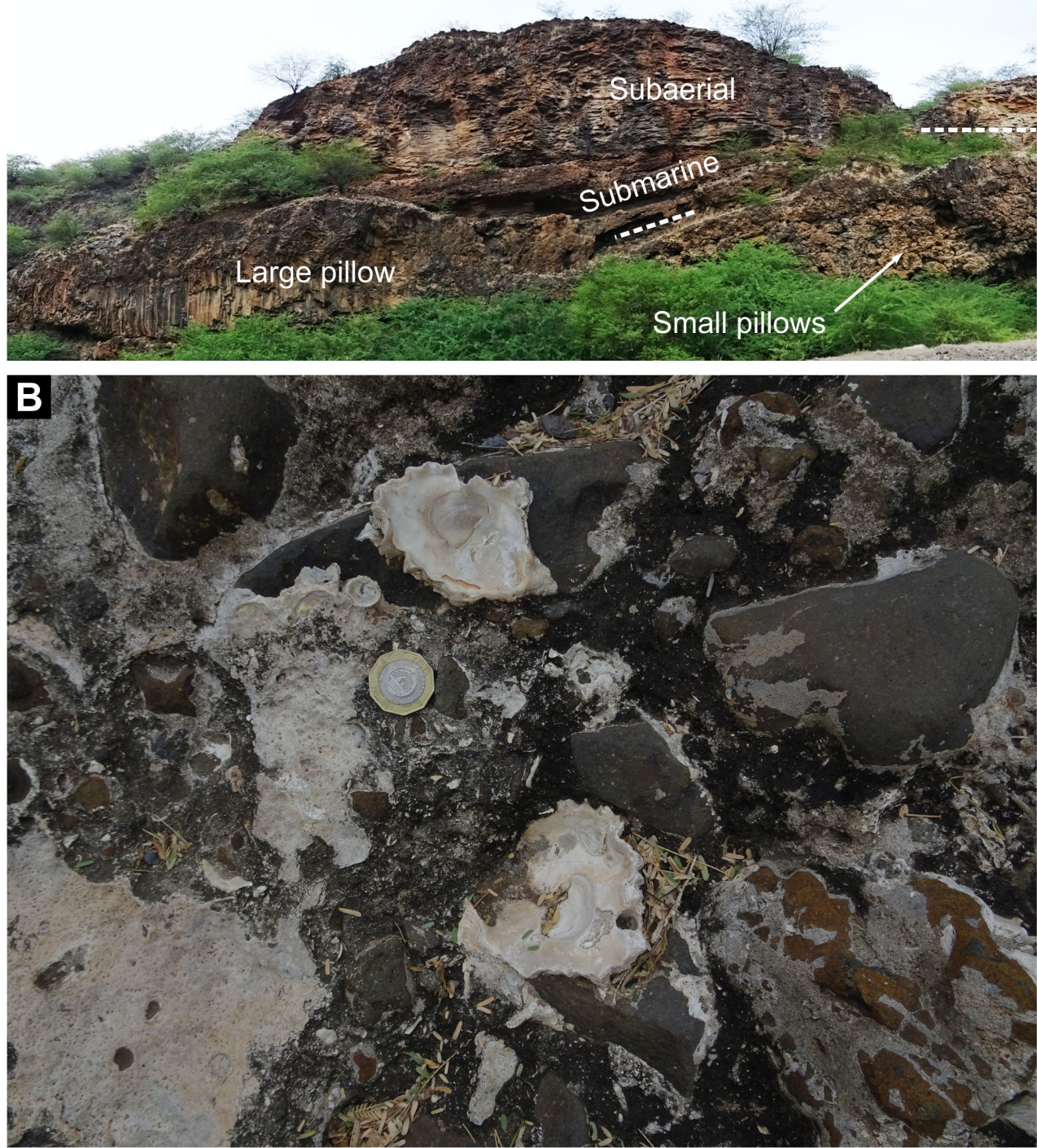

C

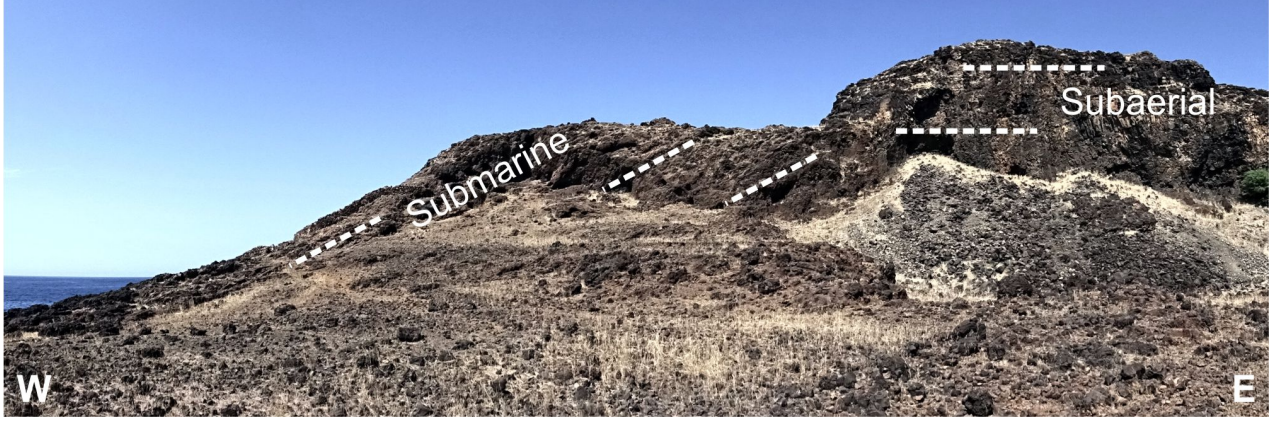
sampled for geochronology; $C$-passage zone observed and sampled on the coast immediately south of Porto Rincão. Location of samples given in Fig. 4. 

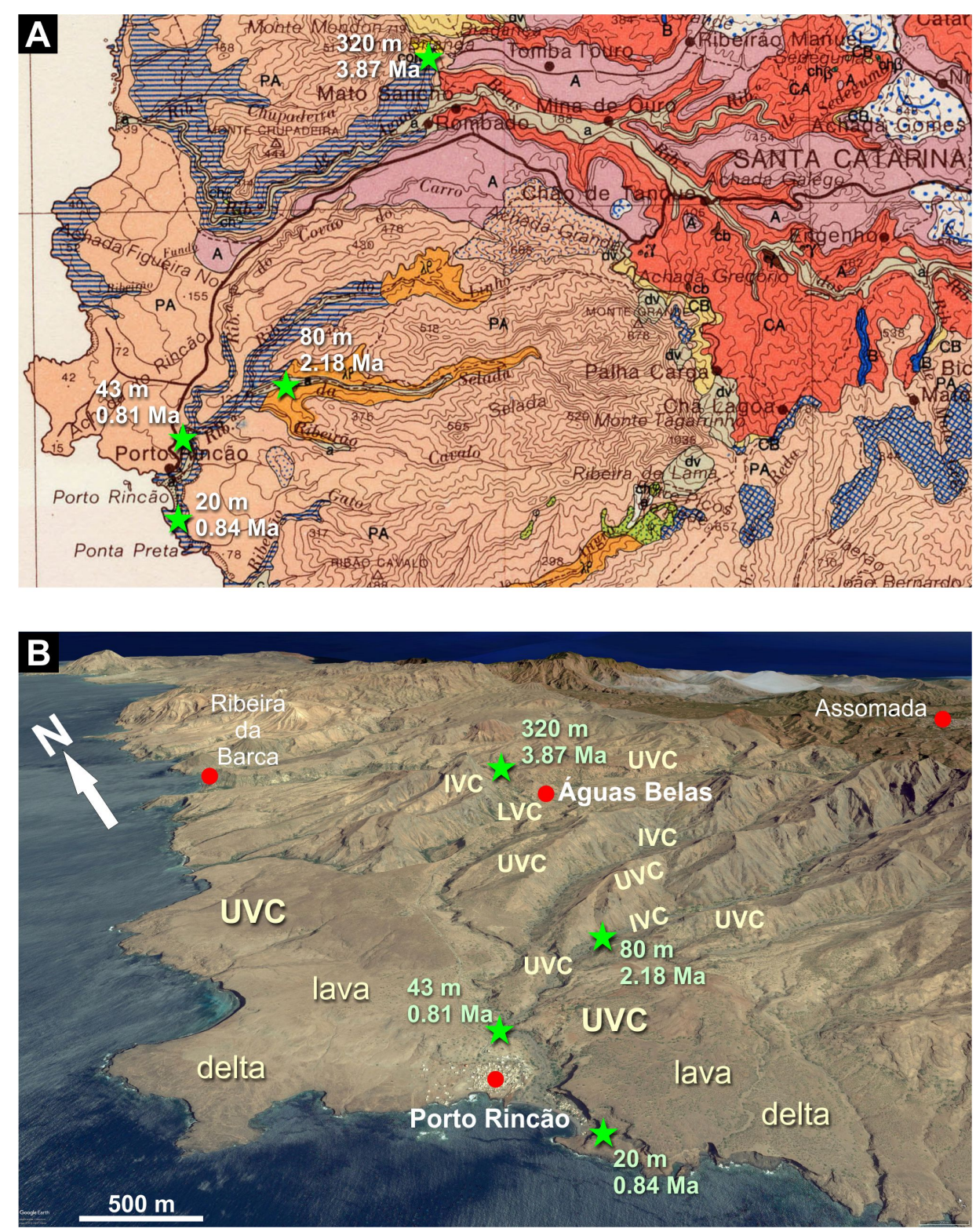

Figure 4. A-geological map of study region (Serralheiro, 1976) annotated with ages reported here. $B$-Perspective view of the topography, distribution of volcanic units, and their geomorphological expression. From the new ages and geomorphology, we infer that the mapped volcanic units are wrongly placed: (1) the Lower Volcanic Complex (LVC, former Flamengos Formation, orange in the geological map) in the Porto Rincão creek is actually the submarine part of the Intermediate Volcanic Complex (IVC, former Pico da Antónia Formation); (2) the submarine

IVC in the Porto Rincão creek (blue horizontal stripes in the geological map) is actually the submarine part of the Upper Volcanic Complex (UVC, former Assomada Formation), which is recognized here for the first time; (3) part of the subaerial IVC (PA and peach colour in the geological map) is actually UVC, which form quite well preserved lava deltas; (4) the submarine IVC in the Águas Belas creek (blue horizontal stripes in the geological map) is actually the entirely 


\section{K-Ar dating}

\subsection{Sampling strategy}

We looked for passage zones and in situ shallow water fossils on pillow lavas (the critical sea level markers) and collected samples in both submarine and subaerial lavas in the Porto Rincão creek. In the absence of these ideal markers, we looked for submarine lavas and collected samples

216 from the base (oldest) and top (youngest) of the lava pile, which was the case in the Águas Belas

217 (western Santiago, immediately north of Porto Rincão creek) and Flamengos (eastern Santiago) 218 creeks.

Sampling was systematically carried out on well-identified lava flows. The central massive part of the lava was extracted by means of hammers and chisels, and broken in-situ with a sledge-

221 hammer to reach the freshest, bubble-free core of the flow and reject any vesicle-rich part. We 222 carefully examined the rock in the field and discarded samples showing traces of weathering.

\subsection{Analytical techniques $-K$-Ar dating on fresh separated groundmass}

Thin sections of all samples were scrutinized to characterize the texture, and ensure the 226 freshness of samples. Most samples are mafic in composition, so the volcanic groundmass was 227 chosen for subsequent geochronological analyses. After crushing and sieving at an adequate grain 228 size (typically 63-125 $\mu \mathrm{m}$ or $125-250 \mu \mathrm{m}$ ), samples were washed in dilute nitric acid and rinsed 229 with deionized water. Magnetic separator and heavy liquids were systematically used to eliminate 230 phenocrysts (olivine, pyroxene, plagioclase), which may carry unsuitable excess-argon, and to 231 extract the unaltered and homogeneous fraction of the groundmass to obtain a meaningful eruption 232 age. 
234 Table 1. Summary of the isotopic ages reported here, with sample locations and references,

235 geographical coordinates, and altitudes. For each sample, the mean age is obtained by weighing by

236 the amount of radiogenic argon. Uncertainties quoted at the $1 \sigma$ level.

\begin{tabular}{|c|c|c|c|c|c|c|c|c|}
\hline $\begin{array}{c}\text { Locality and } \\
\text { sample reference }\end{array}$ & $\begin{array}{l}\text { Latitude } \\
(\mathrm{N})\end{array}$ & $\begin{array}{c}\text { Longitude } \\
(\mathrm{W})\end{array}$ & $\begin{array}{c}\text { Altitude } \\
(\mathrm{m})\end{array}$ & $\mathrm{K}(\%)$ & $\begin{array}{c}40 \mathrm{Ar}^{*} \\
(\%)\end{array}$ & $\begin{array}{c}40 \mathrm{Ar}^{*} \\
\left(10^{12}\right. \\
\mathrm{at} / \mathrm{g})\end{array}$ & $\begin{array}{l}\text { Age } \\
(\mathrm{Ma})\end{array}$ & $\begin{array}{c}\text { Uncertainty } \\
(\mathrm{Ma})\end{array}$ \\
\hline \multicolumn{9}{|l|}{$\begin{array}{l}\text { Flamengos valley } \\
\text { (eastern Santiago) }\end{array}$} \\
\hline \multirow[t]{4}{*}{ ST17I } & 15.16244 & -23.60938 & 48 & 1.699 & 15.6 & 9.079 & 5.11 & 0.08 \\
\hline & & & & & 15.5 & 8.889 & 5.00 & 0.08 \\
\hline & & & & & & mean & 5.06 & 0.08 \\
\hline & 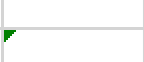 & & & 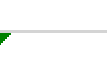 & 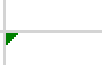 & 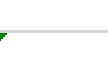 & & $r$ \\
\hline \multirow[t]{3}{*}{ ST17J } & 15.15405 & -23.63730 & 115 & 1.101 & 27.5 & 5.742 & 4.99 & 0.07 \\
\hline & & & & & 28.0 & 5.779 & 5.02 & 0.07 \\
\hline & & & & & & mean & 5.00 & 0.07 \\
\hline \multirow{4}{*}{ ST17L } & 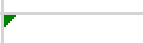 & 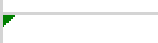 & & 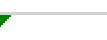 & 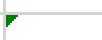 & & & 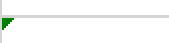 \\
\hline & 15.13284 & -23.66905 & 409 & 0.701 & 13.4 & 2.385 & 3.26 & 0.05 \\
\hline & & & & & 10.1 & 2.448 & 3.34 & 0.06 \\
\hline & & & & & & mean & 3.29 & 0.05 \\
\hline \multicolumn{9}{|l|}{$\begin{array}{c}\text { Porto Rincão } \\
\text { and Águas Belas } \\
\text { valleys } \\
\text { (western Santiago) }\end{array}$} \\
\hline \multirow[t]{3}{*}{ ST17U } & 15.05471 & -23.76369 & 20 & 1.598 & 19.3 & 1.401 & 0.839 & 0.013 \\
\hline & & & & & 16.0 & 1.404 & 0.841 & 0.013 \\
\hline & & & & & & mean & 0.840 & 0.013 \\
\hline \multirow[t]{3}{*}{ ST17X } & 15.06421 & -23.76259 & 43 & 1.608 & 18.0 & 1.359 & 0.809 & 0.012 \\
\hline & & & & & 29.5 & 1.363 & 0.812 & 0.012 \\
\hline & & & & & & mean & 0.811 & 0.012 \\
\hline \multirow[t]{3}{*}{ ST17W } & 15.07013 & -23.75175 & 80 & 2.042 & 19.1 & 4.611 & 2.16 & 0.03 \\
\hline & & & & & 18.0 & 4.687 & 2.20 & 0.03 \\
\hline & & & & & & mean & 2.18 & 0.03 \\
\hline \multirow[t]{3}{*}{ ST17Y } & 15.10868 & -23.73271 & 324 & 0.542 & 4.3 & 2.163 & 3.82 & 0.10 \\
\hline & & & & & 4.6 & 2.223 & 3.92 & 0.10 \\
\hline & & & & & & mean & 3.87 & 0.10 \\
\hline
\end{tabular}


The samples were dated in Laboratory GEOPS (Univ. Paris-Sud, Orsay, France) with the unspiked K-Ar Cassignol-Gillot technique (Gillot and Cornette, 1986; Gillot et al., 2006), which allows the precise determination of small amounts of radiogenic argon $\left({ }^{40} \mathrm{Ar} *\right)$ and is particularly appropriate to date young volcanic rocks, including late quaternary low-K basalts and andesites (e.g., Hildenbrand and Gillot, 2006; Hildenbrand et al, 2003; 2004; 2008; 2012; 2014; 2018; Salvany et al., 2012; Germa et al., 2010, 2011; Quidelleur et al., 2008; Boulesteix et al., 2012; 2013, Costa et al., 2014; 2015; Sibrant et al., 2014, 2015a,b; Ricci et al., 2015, 2018; Silva et al., 2012, 2018; Marques et al., 2015, 2018; Bablon et al., 2018, 2019). The technique has even been extended to the last millennium with an uncertainty of only a few centuries in the case of high-K lavas (Quidelleur et al., 2001). In oceanic environments, it has also been successfully applied to date precisely submarine flows of various ages (Bonneville et al., 2006; Sibrant et al., 2015; Marques et al., 2019).

The analytical data and the new K-Ar ages are presented in Table 1, Supp. Table 1, and Figs. 2 to 5. Decay constants of Steiger and Jäger (1977) were used. Full details on the analytical procedure and performances are given elsewhere (Gillot et al., 2006). The relative uncertainty $\left(\sigma_{\text {age }}\right)$ on each individual age determination is obtained as follows: $\sigma_{\mathrm{age}}=\sqrt{\left(\sigma_{\mathrm{K}}\right)^{2}+\left(\sigma_{\mathrm{cal}}\right)^{2}+\left(\sigma_{A r^{*}}\right)^{2}}$, from the quadratic sum of all three independent sources of uncertainty involved in the calculation: (1) the relative uncertainty on the K-content determination $\left(\sigma_{\mathrm{K}}\right),(2)$ the relative uncertainty on the calibration of the ${ }^{40} \mathrm{Ar}$ signal ( $\left.\sigma_{c a l}\right)$, and (3) the relative uncertainty on the correction of the atmospheric contamination $\left(\sigma_{A r^{*}}=0.1 /{ }^{40} \mathrm{Ar}^{*} \times 100\right),{ }^{40} \mathrm{Ar} *$ being the radiogenic content.

(1) The relative uncertainty on K-content measurement is about $1 \%$, from repeated measurements on standards MDO-G and ISH-G (Gillot and Cornette, 1992), and BCR-2 (Rackzec et al., 2001). For a given sample, repeated $\mathrm{K}$ measurements (usually twice) on distinct aliquots are achieved 
until reaching an average value with a relative standard deviation (RSD) better than $1 \%$ (see supplementary Table 1).

263
(2) The calibration of the ${ }^{40} \mathrm{Ar}$ signal on our mass-spectrometer is obtained by systematic measurements of an air pipette, which is routinely compared to the HD-B1 biotite international standard with its recommended age of 24.21 Ma (Hess and Lippolt, 1994), recently confirmed at $24.18 \pm 0.09 \mathrm{Ma}$ (Schwarz and Trieloff, 2007). The relative uncertainty on the calibration, including the standard uncertainty, is $1 \%$.

(3) The radiogenic argon content $\left(\%^{40} \mathrm{Ar} *\right)$ is measured by comparison of the ${ }^{40} \mathrm{Ar} /{ }^{36} \mathrm{Ar}$ ratio of the sample with an air-pipette, measured under strictly similar Ar pressure conditions. This can be achieved because of the very stable analytic conditions of our mass spectrometer. The limit of detection of the radiogenic Ar content is presently of $0.1 \%$, which allows ages as young as $2 \mathrm{ka}$ to be obtained with only a few centuries uncertainty in favorable cases (Gillot et al., 2006).

For samples with low radiogenic yield $(<10 \%)$, the uncertainty on the age is dominated by the uncertainty on the atmospheric contamination, and can reach several tens of $\%$. For ${ }^{40} \mathrm{Ar}^{*}$ higher than $10 \%$, the uncertainty on the correction of atmospheric contamination becomes negligible, and the total age uncertainty rapidly converges towards $1.4 \%$ (i.e. $\sqrt{(1)^{2}+(1)^{2}}$ ). When the individual ages overlap within their range of uncertainties, the mean age is calculated by weighting each individual age with the amount of radiogenic argon. This method is conservative, as we apply the typical relative uncertainty on $\mathrm{K}(1 \%)$ and ${ }^{40} \mathrm{Ar}(1 \%)$, rather than calculating the age uncertainty from duplicates of each sample, as two or three measurements are not statistically representative. Note that such approach prevents the systematic underestimation of uncertainties when duplicates yield strictly identical values.

Nine independent measurements on HD-B1 standard (Hess and Lippolt, 1994) as an 
284 unknown in the course of the present study yielded a mean age of $24.18 \pm 0.11 \mathrm{Ma}(\mathrm{RSD}=0.46 \%$,

$2851 \sigma$ ), in full agreement with the recommended value of 24.21 Ma (Hess and Lippolt, 1994), ruling

286 out a significant potential bias linked with calibration of our mass spectrometer.

288 Supplementary Table 1. K-content of our samples measured by flame absorption photometry in 289 GEOPS Laboratory (Univ. Paris-Sud, Orsay, France). For each sample, the mean is used as the 290 final $K$-content for age calculation when the relative standard deviation (numbers into brackets) is 291 better than 1\%, in order to account for the total uncertainty including K-solution content and the 292 uncertainty on BCR2 and MDO-G standards (see text).

\begin{tabular}{|c|c|}
\hline Sample & $\mathrm{K}(\%)$ \\
\hline \multirow[t]{2}{*}{ ST17i } & $\begin{array}{l}1.694 \\
1.704 \\
\end{array}$ \\
\hline & Mean: $1.699 \pm 0.007(0.42 \%)$ \\
\hline \multirow[t]{2}{*}{ ST17J } & $\begin{array}{l}1.099 \\
1.104\end{array}$ \\
\hline & Mean: $1.101 \pm 0.004(0.32 \%)$ \\
\hline \multirow[t]{3}{*}{ ST17L } & 0.702 \\
\hline & 0.700 \\
\hline & Mean: $0.701 \pm 0.001(0.16 \%)$ \\
\hline \multirow{4}{*}{ ST17U } & 1.598 \\
\hline & 1.600 \\
\hline & 1.595 \\
\hline & Mean: $1.598 \pm 0.003(0.17 \%)$ \\
\hline \multirow[t]{4}{*}{ ST17X } & 1.612 \\
\hline & 1.599 \\
\hline & 1.612 \\
\hline & Mean: $1.608 \pm 0.007(0.45 \%)$ \\
\hline \multirow[t]{4}{*}{ ST17W } & 2.062 \\
\hline & 2.037 \\
\hline & 2.026 \\
\hline & Mean: $2.042 \pm 0.018(0.91 \%)$ \\
\hline \multirow[t]{2}{*}{ ST17Y } & 0.544 \\
\hline & 0.541 \\
\hline & $0.542 \pm 0.02(0.40 \%)$ \\
\hline
\end{tabular}


Supplementary Table 2. Data necessary to calculate the rates of vertical motion. Sea level data

from Miller et al. (2011).

\begin{tabular}{|c|c|c|c|c|c|c|c|c|c|c|c|}
\hline Sample & $\begin{array}{c}\text { Altitude } \\
\text { (m) }\end{array}$ & $\begin{array}{l}\text { Age } \\
\text { (Ma) }\end{array}$ & $\begin{array}{c}\text { Age } \\
\text { uncertainty } \\
\text { (Ma) }\end{array}$ & $\begin{array}{c}\text { Relative age } \\
\text { uncertainty } \\
(\%)\end{array}$ & $\begin{array}{l}\text { Lowest } \\
\text { sea level } \\
\text { (m) }\end{array}$ & $\begin{array}{c}\text { Highest } \\
\text { sea level } \\
(\mathrm{m})\end{array}$ & $\begin{array}{l}\text { Median } \\
\text { sea level } \\
\text { (m) }\end{array}$ & $\begin{array}{c}\text { Uncertainty } \\
\text { on sea level } \\
\text { (m) }\end{array}$ & $\begin{array}{c}\text { Vertical } \\
\text { displacement } \\
\text { (m) }\end{array}$ & $\begin{array}{l}\text { Uncertainty } \\
\text { vertical } \\
\text { displacement } \\
\text { (m) }\end{array}$ & $\begin{array}{c}\text { Relative } \\
\text { uncertainty } \\
\text { vertical } \\
\text { displacement } \\
\text { (\%) }\end{array}$ \\
\hline ST17X & 43 & 0.811 & 0.012 & 1.5 & -100 & -44.67 & -72 & 28 & 115 & 28 & 24 \\
\hline ST17U & 20 & 0.840 & 0.013 & 1.5 & -59 & -18 & -38 & 20 & 58 & 20 & 35 \\
\hline ST17W & 80 & 2.18 & 0.03 & 1.5 & -67 & -9 & -38 & 29 & 118 & 29 & 25 \\
\hline $121367^{*}$ & 20 & 2.87 & 0.11 & 3.7 & -33 & 6 & -13 & 19 & 33 & 19 & 57 \\
\hline ST17Y & 324 & 3.87 & 0.10 & 2.7 & -35 & -7 & -21 & 14 & 345 & 14 & 4 \\
\hline ST17L & 409 & 3.29 & 0.05 & 1.6 & -61 & -12 & -36 & 24 & 445 & 24 & 5 \\
\hline ST17I & 48 & 5.06 & 0.08 & 1.6 & -29 & 5 & -12 & 17 & 60 & 17 & 29 \\
\hline ST17J & 115 & 5.00 & 0.07 & 1.5 & -29 & 2.67 & -13 & 16 & 128 & 16 & 12 \\
\hline age dat & from 1 & olm et & 2008), & th $u$ & $y$ & & & & & & \\
\hline
\end{tabular}

\section{Rates of vertical motion}

Assuming the uncertainties in both sea level and age, it is possible to estimate a mean rate of vertical movement (and its uncertainty) for each period between the age of the sample and presentday, as follows (see Supp. Table 2):

(1) From the mean K-Ar age of a sample emplaced at sea level (or close), and the available sea maximal, minimal and median sea levels over the period of interest. For instance, our sample ST17X yields a mean age of $811 \pm 12 \mathrm{ka}$, i.e. an age in the interval $799-823 \mathrm{ka}$. From the dataset of Miller et al. (2011), the median sea level during this period was between -100 m and $45 \mathrm{~m}$, i.e. a sea level value of $-72 \pm 28 \mathrm{~m}$. amount of vertical displacement, i.e. uplift (if positive) or subsidence (if negative). In the case of 
our sample ST17X, presently at an altitude of $43 \mathrm{~m}$ (uncertainty on present altitude is here neglected), the estimated mean amount of uplift is thus $43-(-72) \pm 28 \mathrm{~m}=115 \pm 28 \mathrm{~m}$. The relative uncertainty on the amount of vertical motion is thus $(28 / 115) * 100=24 \%$.

(3) The rate of vertical motion is then simply calculated by dividing the amount of vertical displacement by the mean age of the sample. The relative uncertainty on the rate of vertical motion (in \%) is obtained as the sum of the relative uncertainty on the vertical displacement and the relative uncertainty on the age (very small compared to the former). For our sample ST17X, a total relative uncertainty on the rate of uplift of $25 \%$ is thus obtained. A (conservative) mean rate of uplift $0.14 \pm 0.04 \mathrm{~mm} / \mathrm{a}$ is thus estimated for the period between $811 \pm 12 \mathrm{ka}$ and present-

The same approach for each sample gives rates of vertical displacement over different periods and for different sectors of the island (Suppl. Table 2). The rates thus obtained are all 322 positive suggesting at first examination that there has been only uplift during the last $5 \mathrm{Ma}$.

323 However, a closer examination shows that the vertical motion history can be more complex. For 324 instance, the rates obtained over the last $5 \mathrm{Ma}$ (samples ST17 I and J) are one order of magnitude 325 lower than rates obtained on the period 3.3 - 0 Ma (sample ST17L) in the same sector. This suggests a more complex history, where fast uplift may have been followed/preceded by periods

327 with either no uplift at all, or even subsidence. It is thus necessary to use a step-by-step 328 reconstruction to elucidate the more complex history. The new method introduced here works as 329 follows (Figs. 5 and 6): we calculate the original position of the youngest rock unit (UVC, former 330 Assomada), and use it to estimate the vertical displacement and the rate of vertical motion in the most recent period of time. Given that the rock is the youngest, all older rocks must follow the same motion path, which we call the anchor path (Figs. 5 and 6). Following this stage, the number of 
rock units is reduced by one. And then we repeat the process using the second youngest rock unit, until we reach the oldest unit, which must follow all vertical motions of the younger units. More critically, we used paleo-shorelines (inferred from passage zones) at different age and altitude to set anchor points (Fig. 5). Given that all older rocks should show the same rate (assuming only pure vertical motion, i.e no differential movement/tilting), then the calculated path becomes an anchor path, which should be identical to all rocks (cf. blue, black and red dash-dot lines drawn parallel to the anchor green dashed line in Fig. 5). From this step onwards, all rates for older time intervals must be consistent with the anchor points and paths.

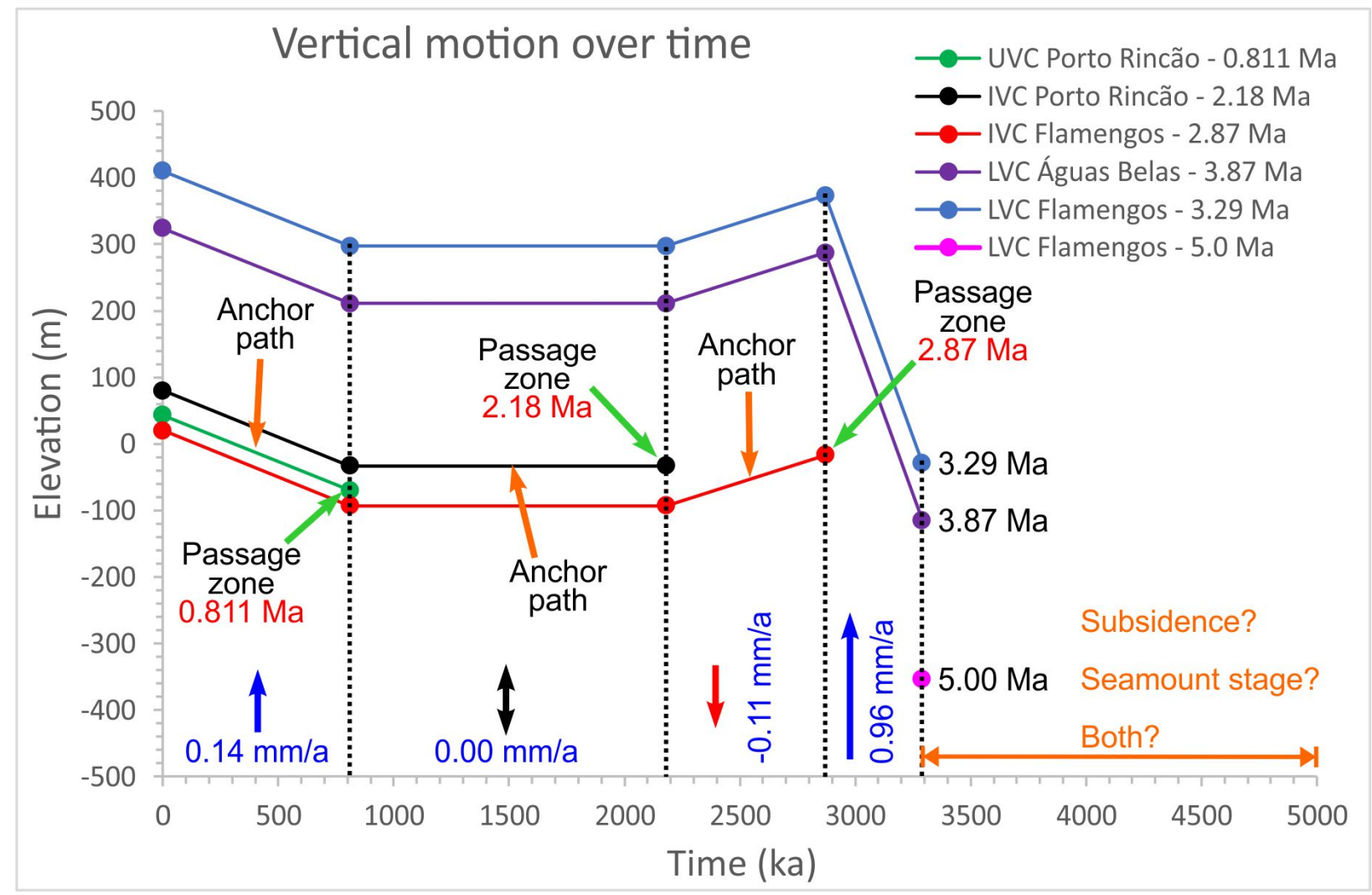

Figure 5. Sketch to show the use of anchor points (passage zones) to construct anchor paths (marked with blue arrows), which must ultimately converge to a check point. The first anchor path calculated to constrain the rates of vertical motion is the youngest (green line), because the most recent vertical motion must be identical to all units in the case of vertical motion alone. By going back in time, we obtain the paleo-positions and vertical motion rates. Note that older rocks follow a path identical to the younger rocks to guarantee that the whole island follows anchor paths. All ages were obtained in the present work, except the 2.87 Ma age reported in Holm et al. (2008). 


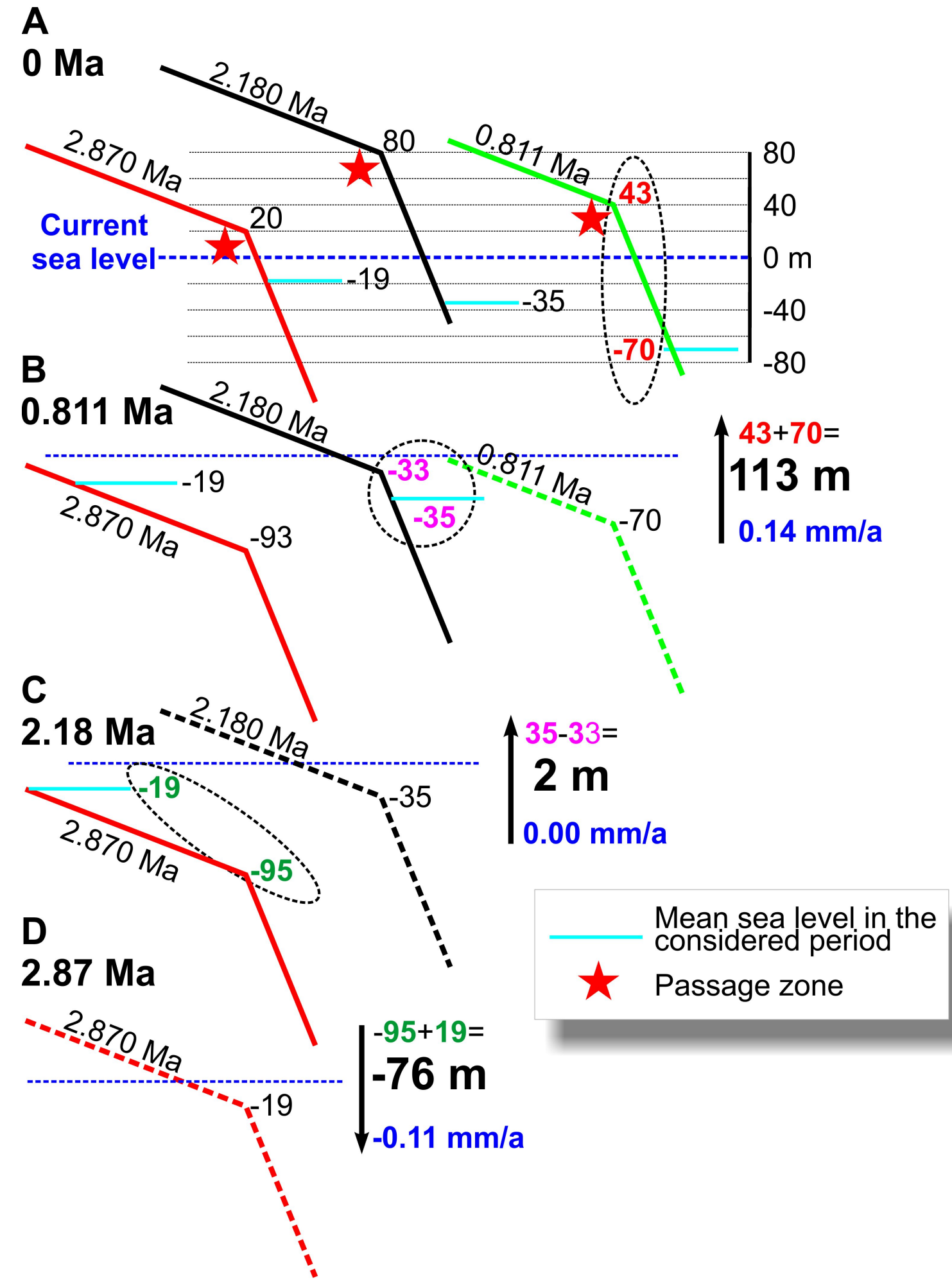

$350 \quad$ Figure 6. Sketch to illustrate the methodology introduced here to estimate vertical motion rates. 351 The blue dashed lines represent current sea level. The sums (black bold numbers) represent vertical 352 displacement (positive for uplift and negative for subsidence). The blue numbers represent the corresponding vertical motion rates. 
Given that the effect of eustatic sea level uncertainty (in the considered time periods) on rate calculations is much greater than the effect of age error, we only consider the former in the calculations. For each period, we can use average or median sea level calculated from the dataset of Miller et al. (2011), which differ at most by only a few meters. Positive and negative vertical motion rates denote uplift and subsidence, respectively.
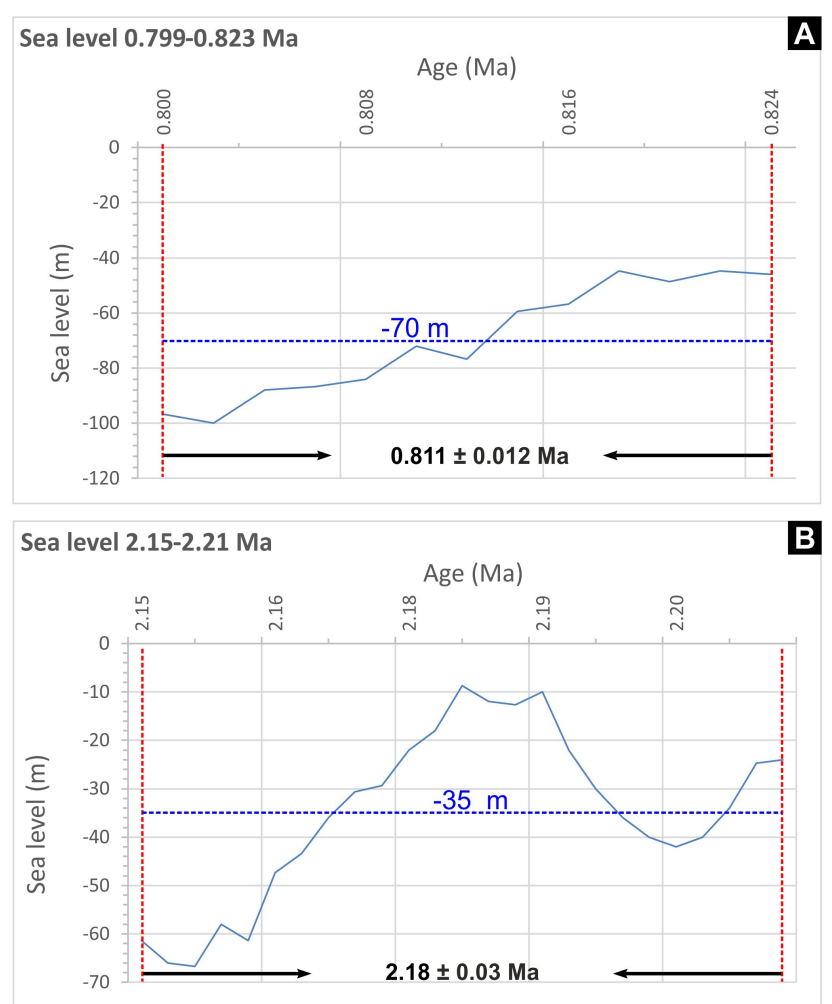

Supplementary Figure 2. Sea level curves from Miller et al. (2011) for the periods indicated in the plots. Mean sea level for each period represented by blue dashed line with respective value.

364 found in the supplementary material. 
368 they belong to the same volcanic unit and so had to undergo the same vertical displacement, which 369 is that of the youngest rock (ca. 3.29 Ma). The highest submarine rocks of Águas Belas (ca. $324 \mathrm{~m}$ ) 370 are not as high as the highest in the opposing Flamengos valley (ca. $410 \mathrm{~m}$ ), but the age of the two 371 rocks is also not the same - greater in the Águas Belas valley (ca. 3.87 Ma) than in the Flamengos 372 valley (ca. 3.29 Ma), which, together with differential erosion, could justify the current difference 373 in altitude $(410-324=86 \mathrm{~m})$. 


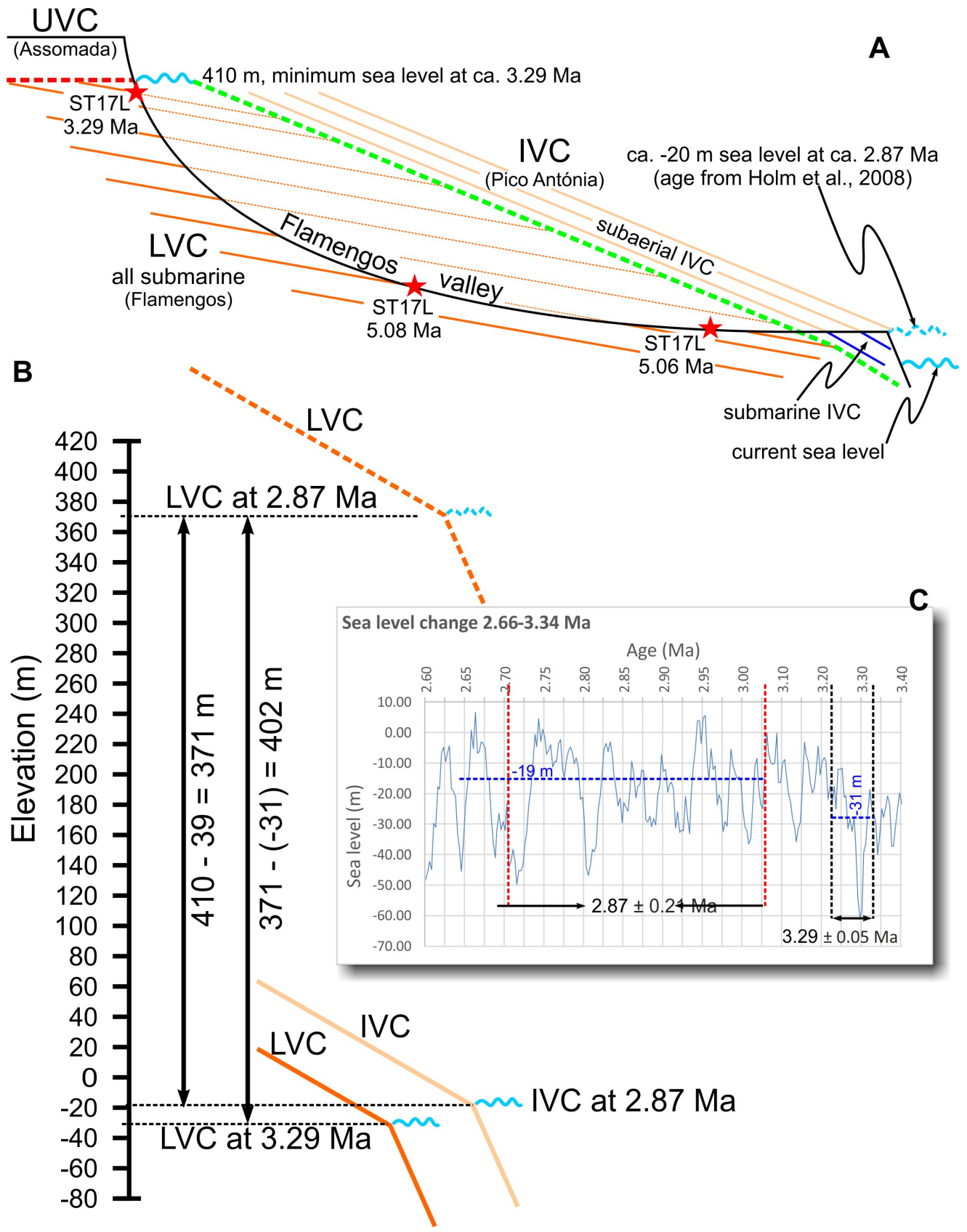

Figure 7. Sketch of the geological setting in the Flamengos valley $(A)$ and graph $(C)$ to illustrate how the minimum uplift rate between 3.29 and $2.87 \mathrm{Ma}$ can be estimated. B-sea level curve between 2.6 and 3.2 Ma (Miller et al., 2011) to show sea level variation in the interval of the $2.87 \pm 0.21 \mathrm{Ma}$ age (Holm et al., 2008). The average sea level in the period is ca. $-20 \mathrm{~m}$, which means that the current altitude of ca. $20 \mathrm{~m}$ of the passage zone corresponds to sea level. LVC-Lower Volcanic Complex (former Flamengos Formation of Serralheiro, 1976);

IVC-Intermediate Volcanic Complex (former Pico da Antónia Formation, which can be subaerial - pink lines, and pass into submarine - blue lines); UVC-subaerial Upper Volcanic Complex (former Assomada Formation). Red dashed line - major unconformity between LVC and UVC; green dashed line-major unconformity between LVC and IVC. 


\section{Discussion}

\subsection{New ages}

From field work in the target area, geomorphological analysis and the new ages reported here (Fig. 4), we have updated and improved previous mapping of the volcanic units: (1) the Lower Volcanic Complex (former Flamengos Formation, orange in the geological map) in the Porto Rincão creek is actually the submarine part of the Intermediate Volcanic Complex (former Pico da Antónia Formation); (2) the submarine Intermediate Volcanic Complex in the Porto Rincão creek

392 (blue horizontal stripes in the geological map) is actually the submarine part of the Upper Volcanic 393 Complex (former Assomada Formation), which is recognized here for the first time; (3) part of the 394 subaerial Intermediate Volcanic Complex (former Pico da Antónia, peach color in the geological map) is actually Upper Volcanic Complex, which form quite well preserved lava deltas; (4) the submarine Intermediate Volcanic Complex in the Águas Belas creek (blue horizontal stripes in the

397 geological map) is actually the entirely submarine Lower Volcanic Complex. The recognition that 398 the geological map is incorrect in critical places suggests that previous work based on the 399 geological map may be erroneous.

\subsection{Rates of vertical motion}

We present a new methodology to deduce vertical motion histories, which can be applied to any island or coastline hosting sequences of paleoshorelines of determinate age. Here we use this

404 methodology and new K-Ar chronostratigraphy to infer the vertical motion history of Santiago

405 Island. We complemented the new methodology with an exercise based on state-of-the-art 406 geochronology and a paleo sea level curve (Miller et al., 2005, 2011). Sensitivity tests indicate that

407 the vertical displacement rates we deduce in a given interval are relatively insensitive to our choice 
408 of eustatic sea level curve (Bintanja et al., 2005; De Boer et al., 2010; Hansen et al., 2013), and

409 came to the conclusion that none can change our results significantly, i.e. none can change

410 subsidence into uplift or vice-versa. In fact, we already show this when we estimate vertical

411 displacement rates using the end-member values in a given interval.

412

Using the geological map of Serralheiro (1976), Ramalho et al. (2010a, c) estimated vertical

413 motion in Santiago, but were unable to find and date passage zones, the critical criterion for an

414 ideal marker of paleo sea level (cf. Table 4 of Ramalho et al., 2010c). They used submarine lavas at

415 ca. $270 \mathrm{~m}$ altitude in the Águas Belas Valley to estimate paleo sea level at ca. 2.8 Ma, because the

416 geological map attributes these rocks to the submarine Intermediate Volcanic Complex (former

417 Pico da Antónia Formation). However, those submarine lavas are dated here about 1 Ma older (ca.

$4183.87 \mathrm{Ma}$ - cf. Fig. 4), which means that they belong to the Lower Volcanic Complex (former

419 Flamengos). Moreover, the new stratigraphy calibrated by isotopic ages indicates that the passage

420 zone within the Intermediate Volcanic Complex (former Pico da Antónia) lies at ca. $80 \mathrm{~m}$ altitude

421 in the Porto Rincão valley (immediately to the south of the Águas Belas valley), which is

422 significantly lower than the $270 \mathrm{~m}$ used by Ramalho et al. (2010a, c). Therefore, the rates estimated

423 by Ramalho et al. $(2010 \mathrm{a}, \mathrm{c})$ are incorrect. Because they were unable to find passage zones,

424 Ramalho et al. (2010a,b,c) dated outcrops of subaerial volcanic units and assumed that underlying

425 submarine units formed at the same time and at a minimum depth below sea level equivalent to the

426 thickness of the submarine unit. However, our fieldwork and dating show that the contact between

427 the subaerial and submarine units is an erosional unconformity and that the subaerial volcanics are

428 at least 2 Ma younger than the underlying submarine rocks. The rates calculated by Ramalho et al.

$429(2010 \mathrm{a}, \mathrm{b}, \mathrm{c})$ therefore underestimate both the minimum paleodepth (since the thickness of the 
431 whole unit is made up of submarine flows, the Lower Volcanic Complex (former Flamengos) can

432 be interpreted in two contrasting ways: (1) the edifice was in a seamount stage, i.e. volcanic growth

433 under sea level, therefore there is no argument in favor of any vertical motion - the older lavas

434 simply formed deeper in the ocean; (2) the edifice was on a subaerial building stage, so that the

435 subaerial lavas at the rim of the proto-island passed into submarine; this means that the submarine

436 lavas formed all at similar depth in the ocean, but were gradually carried to depth by island

437 subsidence between ca. 5 and 3.3 Ma. We do not have an answer to this question because we could

438 neither find passage zones in the LVC, nor fossils on the pillows that could indicate depth.

439 Ramalho et al. (2010a, b, c) concluded for a "general uplift trend over the last $5 \mathrm{Ma}$ " for

440 Santiago. The use of precisely dated passage zones, at different ages $(0.811,2.18$ and $2.87 \mathrm{Ma})$ and

441 in different places on the island led us to a contrasting conclusion: instead of general uplift at a

442 constant rate of ca. $0.092 \mathrm{~mm} / \mathrm{a}$ (Ramalho et al., 2010a, b, c), our new data and procedure indicate

443 that Santiago experienced periods of uplift, at different rates ( 0.95 to $0.14 \mathrm{~mm} / \mathrm{a})$, intercalated with

444 at least one period of subsidence $(-0.11 \mathrm{~mm} / \mathrm{a})$, so improving the temporal resolution of Santiago's

445 vertical motion history.

446 The subsidence period here recognized corresponds to major volcanic construction, i.e. the

447 construction of the most widespread unit in Santiago - the Intermediate Volcanic Complex (former

448 Pico da Antónia). Subsidence may also have occurred during the deposition of the Lower Volcanic

449 Complex, so explaining why this unit is entirely made of submarine lavas.

450

451

6.3. Mechanisms responsible for the vertical displacements of Santiago Island

Having estimated displacements and rates, we now discuss the possible mechanisms responsible for the vertical motions of Santiago Island. Here we will concentrate on two main 
454 mechanisms, one top-down (island loading and unloading) and the other bottom-up (lithosphere 455 thinning, underplating, thermal mantle plume), both directly related to isostasy.

\subsubsection{Top-down: insights from isostatic calculation}

For the top-down mechanism, we do not have enough unloading (erosion in all its forms)

459 data to quantitatively justify the inferred uplifts. However, we have geological information enough

460 to quantitatively explain the subsidence episode in Santiago between ca. 2.9 and 2.2 Ma, which

461 corresponds to the time when the voluminous IVC was being deposited on top of a major

462 unconformity affecting both $\mathrm{BC}$ and LVC. These complexes underwent major erosion prior to the

463 deposition of the IVC, thus comprising one of the main unconformities whose topography peaks at

464 ca. $500 \mathrm{~m}$ altitude (cf. Fig. 2B). Given that the IVC peaks currently at ca. $1400 \mathrm{~m}$, we can use a

465 thickness of $900 \mathrm{~m}$ to calculate the maximum subsidence due to loading. We can estimate the

466 isostatic effect of constructional loading by assuming Airy isostasy (i.e. the lithosphere has zero

467 strength and all loads are locally compensated) and a maximum $900 \mathrm{~m}$ thickness of the IVC:

$468 \varepsilon=900-\left(900 * \rho_{l} / \rho_{a}\right)=900-900 * 2800 / 3200=900-788=112 \mathrm{~m}$

469 where $\varepsilon$ is the topography, $\rho_{l}$ is the density of the lavas, and $\rho_{a}$ is the density of the asthenosphere.

$470112 \mathrm{~m}$ is an upper bound calculation of the isostatic response to constructional loading, therefore

471 indicating that loading by the IVC could potentially account for the inferred ca. $80 \mathrm{~m}$ of subsidence

472 in this period. 
Different bottom-up mechanisms can be responsible for the inferred vertical movements (up

475

476

477

478

479

480

481

482

483

484

485

486

487

488

489

490

491

492

$\rho(T)=\rho\left(T_{0}\right) \cdot\left(1-\alpha\left(T-T_{0}\right)\right) \quad$ Eq. 2

493 where $\rho$ is density $\left[\mathrm{kg} / \mathrm{m}^{3}\right], \alpha$ the thermal expansion coefficient $[1 / \mathrm{K}]$, and $T_{0}$ a reference

494

to $400 \mathrm{~m}$ ): thinning of the lithosphere by basal erosion, and/or crustal underplating, and/or arrival of a hot, low-density material at the base of the lithosphere (thermal mantle plume). We performed a set of 1-D numerical modeling tests to simulate these bottom-up mechanisms by solving the 1-D heat transport equation and calculating the uplift resulting from density variations following crustal thickening or temperature changes. We designed these modeling experiments to best reproduce the observed uplift of Santiago, assuming reasonable input parameters, to assess the viability of each mechanism.

The heat equation to be solved is the following:

$\rho c \frac{\partial T}{\partial t}=A+k \frac{\partial^{2} T}{\partial z^{2}}$

where $T$ is the temperature $\left[{ }^{\circ} \mathrm{C}\right], t$ the time $[\mathrm{s}], z$ the depth $[\mathrm{m}], \rho$ the density $\left[\mathrm{kg} / \mathrm{m}^{3}\right], c$ the mass heat capacity $[\mathrm{J} /(\mathrm{kg} * \mathrm{~K})]$, and $k$ the thermal conductivity $[\mathrm{W} /(\mathrm{m} * \mathrm{~K})]$. The boundary conditions are fixed temperatures at the top and bottom of the model domain, respectively $0{ }^{\circ} \mathrm{C}$ and $1300{ }^{\circ} \mathrm{C}$ (considered to be the normal asthenospheric temperature). We used standard values of $k=2.2$ $\mathrm{W} /\left(\mathrm{m}^{*} \mathrm{~K}\right)$ and $c=1000 \mathrm{~J} /\left(\mathrm{kg}^{*} \mathrm{~K}\right)$ for the crust (gabbro), and $k=3 \mathrm{~W} /(\mathrm{m} * \mathrm{~K})$ and $c=1000 \mathrm{~J} /\left(\mathrm{kg}^{*} \mathrm{~K}\right)$ for the mantle (peridotite) (Robertson, 1988). Heat production was $0.2 \mu \mathrm{W} / \mathrm{m}^{3}$ for the crust and $0.02 \mu \mathrm{W} / \mathrm{m}^{3}$ for the mantle.

Density is related to temperature through the following equation:

$$
\text { temperature at which density is } \rho_{0} \text {. This reference temperature is taken as } 0{ }^{\circ} \mathrm{C} \text { for crustal materials }
$$

Eq. 1 
495 and $1300{ }^{\circ} \mathrm{C}$ for the mantle. The thermal expansion coefficient is taken as $3.5 * 10^{-5} \mathrm{~K}^{-1}$ for all

496 materials (Afonso et al., 2005). As reference density we used $\rho_{0}=2800 \mathrm{~kg} / \mathrm{m}^{3}$ for the crust and 3200

$497 \mathrm{~kg} / \mathrm{m}^{3}$ for the mantle.

498 Several works have investigated the nature and properties of the lithosphere in the Cape 499 Verde Swell (Ali et al., 2013; Carvalho et al., 2019; Dash et al., 1976; Hellfrich et al., 2010; Lodge 500 and Helffrich, 2006; McNuttt, 1988; Pim et al., 2008; Vinnik et al., 2012; Wilson et al., 2010, 501 2013). Fundamental for the modeling are the thicknesses suggested in those works for the 502 lithosphere and the oceanic crust, which vary from $60 \mathrm{~km}$ (Carvalho et al. (2019) to $100 \mathrm{~km}$ (Lodge 503 and Helffrich, 2006) for the former, and from $7 \mathrm{~km}$ (e.g. Pim et al., 2008; Wilson et al., 2010) to 15 $504 \mathrm{~km}$ for the latter (Dash et al., 1976). Therefore, we tested initial lithosphere configurations with 505 crustal thicknesses of $7 \mathrm{~km}$ and $15 \mathrm{~km}$, and lithosphere thickness of 80 and $100 \mathrm{~km}$. Topography 506 was calculated assuming local isostatic equilibrium using the following equation (Lachenbruch and 507 Morgan, 1990):

$508 \varepsilon=\frac{\rho_{a}}{\rho_{a}-\rho_{w}}\left(\frac{\rho_{a}-\rho_{L}}{\rho_{a}} H+\varepsilon_{0}\right)$ Eq. 3

509 where $\varepsilon$ is the topography [m], $\rho_{a}$ the asthenospheric density $\left(3200 \mathrm{~kg} / \mathrm{m}^{3}\right), \rho_{L}$ the average 510 lithospheric density, $\rho_{W}$ the density of sea water $\left(1030 \mathrm{~kg} / \mathrm{m}^{3}\right), H$ the thickness of the lithosphere $511[\mathrm{~m}]$, and $\varepsilon_{0}$ the reference topography of an unloaded asthenosphere $(-2400 \mathrm{~m})$. In the results presented below, the beginning of the calculations corresponds to $3.3 \mathrm{Ma}$ ago, 513 because this is the age of the first recognized major uplift. We present for the different models 2 to 5143 calculations in order to show that different initial configurations combined with different 515 structural modifications can explain the uplift. 
517 Model 1: Lithospheric thinning

518 The temperature at the initial depth $(80$ or $100 \mathrm{~km})$ is maintained constant at $1300{ }^{\circ} \mathrm{C}$ during 519 the whole calculation. Between 0 and $0.4 \mathrm{Ma}$ in the simulation (3.3 to 2.9 Ma in nature), the base of 520 the lithosphere rises from $100 \mathrm{~km}$ to $60 \mathrm{~km}$ in steps of $5 \mathrm{~km} / 0.05 \mathrm{Ma}$ (blue line in Fig. 8A) or from 52180 to $44 \mathrm{~km}$ in steps of $4 \mathrm{~km} / 0.05 \mathrm{Ma}$ (orange line in Fig. 8A), resulting in a total topographic uplift 522 of ca. $470 \mathrm{~m}$. From 0.4 to $2.5 \mathrm{Ma}$ (2.9 to $0.8 \mathrm{Ma}$ in nature), the temperature relaxes, and the 523 lithosphere thickens slowly, resulting in a subsidence of $50 \mathrm{~m}$. At $2.5 \mathrm{Ma}(0.8 \mathrm{Ma}$ in nature), a new 524 pulse of lithosphere heating is simulated by thinning the lithosphere again to $60 \mathrm{~km} / 44 \mathrm{~km}$, and 525 maintaining the base of the lithosphere (i.e. a temperature of $\left.1300^{\circ} \mathrm{C}\right)$ at this depth until $3.3 \mathrm{Ma}(0$ 526 Ma in nature), which results in another uplift of ca. $200 \mathrm{~m}$. The topography rises higher than at 0.4 527 Ma because the crust has meanwhile been heated as well. Both models give very similar results. 


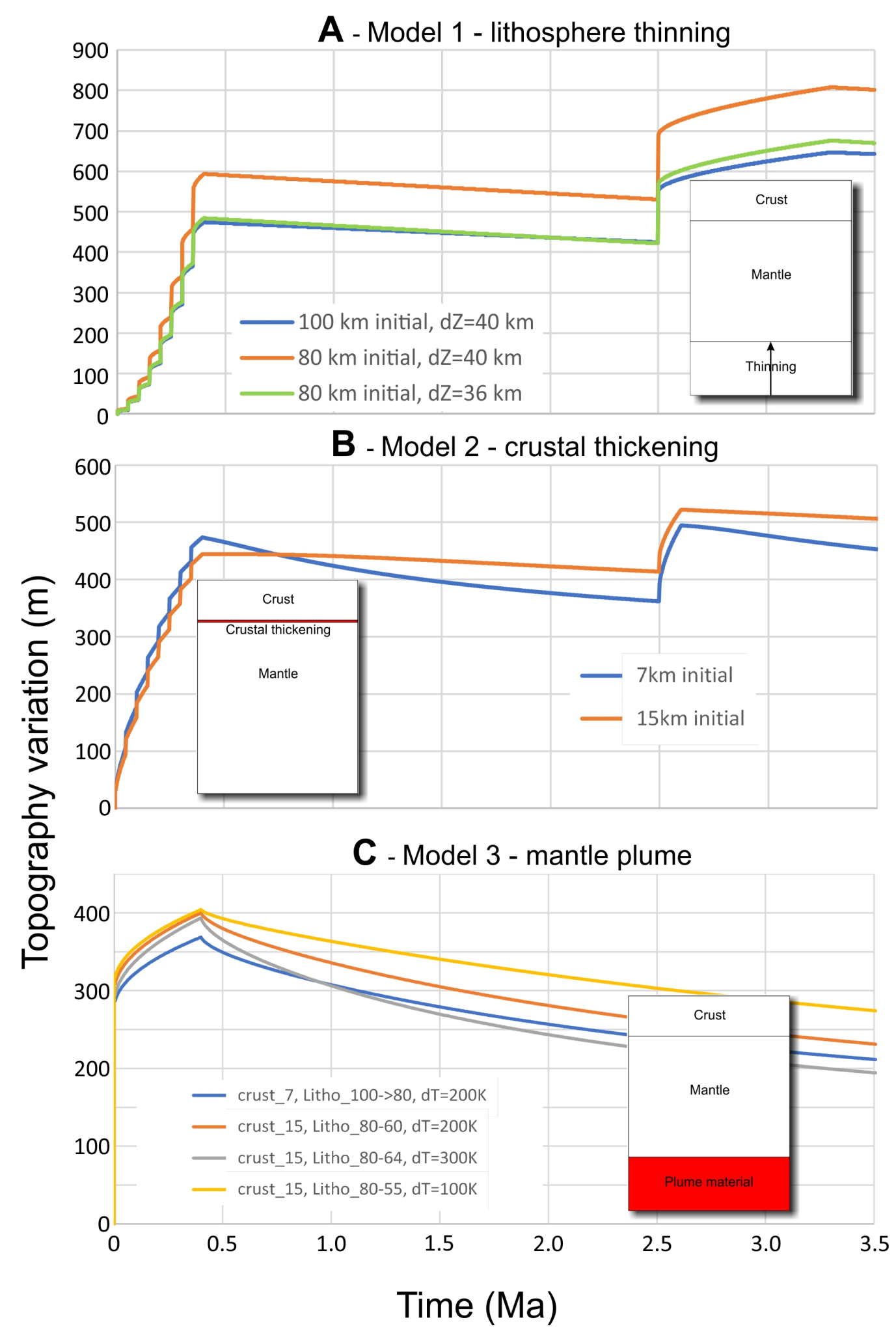

Figure 8. Numerical modeling of the topography variation over time resulting from the Airy 531 isostatic response to (A) lithospheric thinning as specified in Model 1, (B) underplating as specified 532 in Model 2, and (C) excess buoyancy associated with a mantle plume as specified in Model 3. 
Model 2: Crustal thickening (underplating)

The crust thickens by a total of $800 \mathrm{~m}$ (from 7 to $7.8 \mathrm{~km}$, blue line in Fig. $8 \mathrm{~B}$, and from 15 to $15.8 \mathrm{~km}$, orange line in Fig. $8 \mathrm{~B}$ ) between 0 and $0.4 \mathrm{Ma}$ (3.3 to $2.9 \mathrm{Ma}$ in nature). Material arrives at $1100{ }^{\circ} \mathrm{C}$, the typical temperature of a basaltic magma, its temperature is maintained constant until $0.4 \mathrm{Ma}$ (2.9 Ma in nature) to simulate a constant supply and heating of the surrounding layers during the whole process. This results in a topographic uplift of $460 \mathrm{~m}$. After $0.4 \mathrm{Ma}$ (2.9 Ma in nature), the temperature relaxes and topography decreases slightly. At $2.5 \mathrm{Ma}(0.8 \mathrm{Ma}$ in nature), another pulse of thickening of $100 \mathrm{~m}(7.8$ to $7.9 \mathrm{~km})$ is simulated, again with a temperature of 1100 ${ }^{\circ} \mathrm{C}$ that is maintained during $0.1 \mathrm{Ma}$. After $0.8 \mathrm{Ma}$ (at $3.3 \mathrm{Ma}=0 \mathrm{Ma}$ in nature), it results in an uplift of $100 \mathrm{~m}$, including the partial temperature relaxation between 2.6 and $3.3 \mathrm{Ma}$ ( 0.7 to $0 \mathrm{Ma}$ in nature). The effect of relaxation is stronger for the initially thinner crust, which, when taking into account the observation of roughly stable topography during this period, would give a preference for the model with thicker initial crust.

\section{Model 3: Rise of a thermal plume}

In this model, hot material (thermal mantle plume) arrives at the base of the lithosphere and replaces it in a variable thickness depending on plume temperature. We modeled temperature differences between 100 and $300{ }^{\circ} \mathrm{C}$, i.e. plume material at 1400 to $1600{ }^{\circ} \mathrm{C}$. The temperature is maintained identical until $0.4 \mathrm{Ma}$ (2.9 Ma in nature), then it relaxes. In order to achieve the desired total topographic uplift of about $400 \mathrm{~m}$, the thickness of the plume material layer must vary between $25 \mathrm{~km}$ for a $1400{ }^{\circ} \mathrm{C}$ plume and $16 \mathrm{~km}$ for a $1600{ }^{\circ} \mathrm{C}$ plume. The effect is thus nearly linear with the temperature difference. However, subsidence is much more important for hotter 
material. A simple model as presented here would therefore not be compatible with the observations. Nevertheless, a continuous supply of hot material between 2.9 and 0.8 Ma ago would maintain the topography at the observed height. We did not model the second pulse at $2.5 \mathrm{Ma}(0.8$ Ma in nature), since the other models show that the necessary topography variation can be easily achieved.

For the quantitative interpretation, a critical condition is the one of local isostasy. Significant elastic strength would reduce the topographic response. However, on the one hand, the volcanism in Cape Verde indicates a locally hot and therefore weaker lithosphere. On the other hand, especially for models 2 and 3, the structural variations used for the models are quite modest: doubling crustal thickening or the thickness of the hot plume layer would certainly not be exaggerated. It would be more difficult to consider much stronger thinning of the lithosphere in Model 1 without the additional effect of hot rising plume material. Anyhow, also a combination of all models would be able to explain the inferred uplift. The question now is application of the model results to Santiago in the context of the archipelago and the Cape Verde Rise. Most largescale geophysical studies carried out in the Cape Verde Swell suggest that upwelling within the asthenosphere supports the anomalous topography of the Cape Verde Swell, with minor contributions from local thickened oceanic crust and, perhaps, partial thermal rejuvenation of the lithospheric mantle. If large-scale swelling (dynamic uplift at the scale of the whole archipelago; e.g. Huppert et al., 2020) were the mechanism responsible for island uplift, then one would expect to find similar uplift in islands with similar age, which is not the case (e.g. Ramalho et al., 2010a, b, c). Therefore, the solution to explain geological evidence should come from local mechanisms.

Model 1 is intended to simulate extension, which does not seem a sensible option in the geodynamic setting of Cape Verde where rifting has never been recognized. In contrast, Model 3 
578 looks like a good option, because this model simulates the scenario whereby the mantle plume

579 dynamically uplifts the lithosphere underlying the Cape Verde Islands during Santiago's evolution,

580 but is inconsistent with what is known about the differential vertical motion among the Cape Verde

581 islands (e.g. Ramalho et al., 2010a, b, c), because some islands show large uplifts (e.g. Santiago and

582 S. Nicolau), but other islands do not record uplift (e.g. Santo Antão and Fogo). Therefore, the large-

583 scale plume (regional mechanism) cannot explain the differential uplift. The solution is therefore to

584 look for a local mechanism, which is the case of magma underplating (Model 2), as already

585 suggested to exist beneath the islands (e.g. Lodge and Helffrich, 2006; Ramalho et al., 2010b;

586 Vinnik et al., 2012; Wilson et al., 2010).

587

588

\section{Conclusions}

We use paleoshorelines at different altitude and age to constrain the vertical motion history

590 of Santiago Island. Specifically, we calculate the time-averaged vertical motion rates required to

591 explain the present-day elevations of the dated sequence of paleoshorelines. We account for eustatic

592 sea level changes and work progressively back in time to incorporate the more recent vertical

593 motion rates implied by the youngest paleoshorelines into the vertical motion history of all older

594 shorelines. We thus obtain a vertical motion history consisting of time-averaged vertical motion

595 rates spanning the five intervening time periods between paleoshoreline formation and the present

596 day: (1) > $6 \mathrm{Ma}$ - this stage is certainly mostly submarine (seamount growth), but there is no

597 consensus regarding the submarine or subaerial nature of the rocks of the Basement Complex

598 currently cropping out onshore: all submarine, or subaerial in part? Did the seamount grow into an

599 island with subaerial volcanism? (2) 5.06 to $3.29 \mathrm{Ma}$ - given that all known rocks in this period are

600 submarine, they can represent seamount growth or island subsidence. (3) 3.29 to $2.87 \mathrm{Ma}$ - fast 
601 uplift (0.96 mm/a) mostly responsible for putting submarine lavas currently close to $410 \mathrm{~m}$ altitude.

602 (4) 2.87 to $2.18 \mathrm{Ma}$ - relatively fast subsidence $(-0.11 \mathrm{~mm} / \mathrm{a})$, most likely due to the fast volcanic

603 growth of the most voluminous volcanic unit on the island, the Intermediate Volcanic Complex

604 (former Pico da Antónia Formation). (5) 2.18 to $0.811 \mathrm{Ma}$ - stationary island (0.00 mm/a). (6)

6050.811 to $0 \mathrm{Ma}$ - relatively fast uplift $(0.14 \mathrm{~mm} / \mathrm{a})$.

606 The advantage of using dated passage zones, at different ages $(0.811,2.18$ and $2.87 \mathrm{Ma})$ and

607 in different places on the island, and a different procedure is that we find a more detailed history of

608 vertical motion consistent with geological observation. Instead of a simple general uplift at a

609 constant rate of ca. $0.092 \mathrm{~mm} / \mathrm{a}$ (Ramalho et al., 2010a, b, c), our new data and methodology

610 indicate that Santiago experienced several periods of uplift, at different rates (0.95 to $0.14 \mathrm{~mm} / \mathrm{a})$,

611 intercalated with at least one period of subsidence $(-0.11 \mathrm{~mm} / \mathrm{a})$.

612 We numerically tested top-down (volcanic loading) and bottom-up (lithosphere thinning,

613 underplating and mantle plume) mechanisms to explain the inferred vertical movements, and we

614 conclude that volcanic loading and crustal underplating are capable of producing the observed

615 subsidence and uplift, respectively.

616

617 Acknowledgments

618 This is a contribution to Project MEGAHazards2 (PTDC/GEO-GEO/0946/2014), funded by

619 FCT, Portugal. The sea level data used in this study was kindly supplied by Kenneth Miller, and

620 can be found here: https://www.ncdc.noaa.gov/paleo-search/study/13947. Thorough and

621 constructive reviews by five anonymous Reviewers helped to clarify and improve the quality of this

622 manuscript.

623 


\section{References}

Afonso, J.C., Ranalli, G., Fernàndez, M., 2005. Thermal expansivity and elastic properties of the lithospheric mantle: results from mineral physics of composites. Phys. Earth Planet. Int. 149, 279-306. Doi: 10.1016/j.pepi.2004.10.003.

Ali, M. Y., A. B. Watts, \& I. Hill, 2003. A seismic reflection profile study of lithospheric flexure in the vicinity of the Cape Verde Islands. J. Geophys. Res. 108, 2239, doi:10.1029/2002JB002155.

Bernard-Griffiths, J., Cantagrel, J.-M., Alves, C., Mendes, F., Serralheiro, A. \& Macedo, J., 1975. Geochronologie: Donnés radiometriques potassium/argon sur quelques formations magmatiques des îlles de l'archipel du Cap Vert. Comptes Rendus des Seances de l'Academie des Sciences D280, 2429-2432.

Bintanja, R., van de Wal, R.S.W., Oerlemans, J., 2005. Modelled atmospheric temperatures and global sea levels over the past million years. Nature 437 (7055), 125-128.

Bonneville, A., Dosso, L., Hildenbrand, A., 2006. Temporal evolution and geochemical variability of the South Pacific superplume activity. Earth and Planetary Science Letters, 244(1-2):251-269.

Boulesteix, T., Hildenbrand, A., Gillot, P.Y., Soler, V., 2012. Eruptive response of oceanic islands to giant landslides: New insights from the geomorphologic evolution of the Teide-Pico Viejo volcanic complex (Tenerife, Canary). Geomorphology, 138 (1), 61-73.

Boulesteix, T., Hildenbrand, A., Soler, V., Quidelleur, X., Gillot, P.Y., 2013. Coeval giant landslides in the Canary Islands: Implications for global, regional and local triggers of giant flank collapses on oceanic volcanoes. Journal of Volcanology and Geothermal Research, 257, 90-98.

Carvalho, J., Bonadio, R., Silveira, G., Lebedev, S., Mata, J., Arroucau, P., s Meier, T., Celli, N.L., 2019. Evidence for high temperature in the upper mantle beneath Cape Verde archipelago from 
Rayleigh-wave phase-velocity measurements. Tectonophysics 770, 228225.

648

649

650

651

652

653

654

655

656

657

658

659

660

661

662

663

664

665

666

667

668

669

Cas, R., \& Wright, J., 1987. Volcanic successions. modern and ancient: a geological approach to processes, products and successions. London, UK: Chapman \& Hall.

Costa, A.C.G., Marques, F.O., Hildenbrand, A., Sibrant, A.L.R., Catita, C.M.S., 2014. Large-scale catastrophic flank collapses in a steep volcanic ridge: the Pico-Faial Ridge, Azores Triple Junction. Journal of Volcanology and Geothermal Research, 272, 111-125.

Costa, A.C.G., Hildenbrand, A., Marques, F.O., Sibrant, A.L.R., Santos de Campos, A., 2015. Catastrophic flank collapses and slumping in Pico Island during the last 130 kyr (Pico-Faial ridge, Azores Triple Junction). J. Volcanol. Geotherm. Res., 302, 33-46.

Dash, B.P., Ball, M.M., King, G.A., Butler, L.W., Rona, P.A., 1976. Geophysical investigation of the Cape Verde archipelago. J. Geophys. Re. 81, 5249-5259.

de Boer, B., Van de Wal, R.S.W., Bintanja, R., Lourens, L.J., Tuetter, E., 2010. Cenozoic global ice-volume and temperature simulations with 1-D ice-sheet models forced by benthic $\delta 180$ records. Ann. Glaciol. 51, 23-33. Doi:10.3189/172756410791392736.

Germa, A., Quidelleur, X., Gillot, PY., Tchilinguirian, P., 2010. Volcanic evolution of the back-arc Pleistocene Payun Matru volcanic field (Argentina). Journal of South American Earth Sciences $29,717-730$.

Germa, A., Quidelleur, X., Lahitte, P., Labanieh, S. \& Chauvel, C., 2011. The K-Ar CassignolGillot technique applied to western Martinique lavas: a record of Lesser Antilles arc activity from 2 Ma to Mount Pelée volcanism. Quat. Geochronol. 6, 341-355.

Gillot, P. Y., Cornette, Y., 1986. The Cassignol technique for potassium-argon dating, precision and accuracy - examples from the Late Pleistocene to recent volcanics from southern Italy. Chem. Geol. 59, 205-222. 
670 Gillot, P. Y., Cornette, Y., Max, N., Floris, B., 1992. Two reference materials, trachytes MDO-G

671 and ISH-G, for argon dating (K-Ar and Ar-40/Ar-39) of Pleistocene and Holocene

672 rocks. Geostandards Newsletter 16, 55-60.

673 Gillot, P. Y., Hildenbrand, A., Lefevre, J. C., Albore-Livadie, C., 2006. The K-Ar dating method:

674 principle, analytical techniques and application to Holocene volcanic eruptions in Southern

$675 \quad$ Italy. Acta Vulcanol. 18, 55-66.

676 Hansen, J., Sato, M., Russell, G., Kharecha, P., 2013. Climate sensitivity, sea level and atmospheric

677 carbon dioxide. Phil Trans R Soc A 371: 20120294. Doi: 10.1098/rsta.2012.0294.

678 Hellfrich, G., Faria, B., Fonseca, J.F.B.D., Lodge, A., Kaneshima, S., Month, 2010. Transition zone

679 structure under a stationary hot spot: Cape Verde. Earth Planet. Sci. Lett. 289, 156-161.

$680 \quad$ https://doi.org/10.1016/j.eps1.2009.11.001.

681 Hess, J.C., and H. J. Lippolt. Compilation of K-Ar measurements on HD-B1 standard biotite.

682 Phanerozoic Time Scale,.Bull. Liais. Inform. IUGS Subcomm. On Geochrono. Int. Geol. Correl.

683 Program. Paris 12, 19-23 (1994).

684 Hildenbrand, A., Gillot, P.Y., 2006. Evidence for a differentiated ignimbritic activity ending the 685 building-stage of Tahiti-Nui (French Polynesia). Comptes Rendus Geosciences 338, 280-287.

686 Hildenbrand, A., Gillot, P.Y., Soler, V., Lahitte, P., 2003. Evidence for a persistent uplifting of La

687 Palma (Canary Islands) inferred from morphological and radiometric data, Earth Planetary

$688 \quad$ Science Letters 210, 277-289.

689 Hildenbrand, A., Gillot, P.Y., Le Roy, I., 2004. Volcano-tectonic and geochemical evolution of an 690 oceanic intra-plate volcano: Tahiti-Nui (French Polynesia). Earth Planetary Science Letters 217, $691 \quad 349-365$.

692 Hildenbrand, A., Madureira, P., Marques, F.O., Cruz, I., Henry, B., Silva, P., 2008. Multi-stage 
evolution of a sub-aerial volcanic ridge over the last 1.3 Myr: S. Jorge Island, Azores Triple Junction. Earth and Planetary Science Letters 273, 289-298.

Hildenbrand, A., Marques, F.O., Costa, A.C.G., Sibrant, A.L.R., Silva, P.F., Henry, B., Miranda, J.M., Madureira, P., 2012. Reconstructing the architectural evolution of volcanic islands from combined K-Ar, morphologic, tectonic, and magnetic data: the Faial Island example (Azores). Journal of Volcanology and Geothermal Research, 241-242, 39-48.

Hildenbrand A., Weis D., Madureira P., Marques F.O., 2014. Recent plate re-organization at the Azores Triple Junction: evidence from combined geochemical and geochronological data on Faial, S. Jorge and Terceira volcanic islands. Lithos 210-211, 27-39.

Hildenbrand, A., Marques, F.O., Catalão, J., 2018. Large-scale mass wasting on small volcanic islands revealed by the study of Flores Island (Azores). Scientific Reports 8, 13898.

Holm, P.M., Grandvuinet, T., Friis, J., Wilson, J.R., Barker, A.K., Plesner, S., 2008. An ${ }^{40} \mathrm{Ar}^{3}{ }^{39} \mathrm{Ar}$ study of the Cape Verde hot spot: Temporal evolution in a semistationary plate environment. J. Geophys. Res. 113, B08201, doi:10.1029/2007JB005339.

Huppert, K.L., Perron, J.T., \& Royden, L.H. (2020). Hotspot swells and the lifespan of volcanic ocean islands. Science Advances, 6(1), eaaw6906.

Huppert, K.L., Royden, L.H., Perron, J.T., 2015. Dominant influence of volcanic loading on vertical motions of the Hawaiian Islands. Earth and Planetary Science Letters 418, 149-171.

Jones, J.G., 1969. Pillow lavas as depth indicators. American Journal of Science 267, 181-195.

Jones, J., \& Nelson, P., 1970. The flow of basalt lava from air into water, its structural expression and stratigraphic significance. Geological Magazine 107, 13-19.

Lachenbruch, A.H., Morgan, P., 1990. Continental extension, magmatism and elevation: Formal relations and rules of thumb. Tectonophysics 174, 39-62. 
716 Lodge, A., Helffrich, G., 2006. Depleted swell root beneath the Cape Verde Islands. Geology 34, $717 \quad 449-452$.

718 Marques, F.O., Catalão, J.C., DeMets, C., Costa, A.C.G., Hildenbrand, A., 2013. GPS and tectonic 719 evidence for a diffuse plate boundary at the Azores Triple Junction. Earth and Planetary $720 \quad$ Sciences Letters 381, 177-187.

721 Marques, F.O., Catalão, J.C., Hildenbrand, A., Costa, A.C.G., Dias, N.A., 2014. The 1998 Faial 722 earthquake, Azores: Evidence for a transform fault associated with the Nubia-Eurasia plate 723 boundary? Tectonophysics $633,115-125$.

724 Marques, F.O., Catalão, J.C., Hildenbrand, A., Madureira, P., 2015. Ground motion and tectonics in 725 the Terceira Island: Tectonomagmatic interactions in an oceanic rift (Terceira Rift, Azores 726 Triple Junction). Tectonophysics 651-652, 19-34.

727 Marques, F.O., Hildenbrand, A., Hübscher, C., 2018. Evolution of a volcanic island on the shoulder 728 of an oceanic rift and geodynamic implications: S. Jorge Island on the Terceira Rift, Azores 729 Triple Junction. Tectonophysics 738, 41-50.

730 McNutt, M., 1988. Thermal and mechanical properties of the Cape Verde Rise. J. Geophys. Res. $73193,2784-2794$.

732 Miller, K.G., Kominz, M.A., Browning, J.V., Wright, J.D., Mountain, G.S., Katz, M.E., Sugarman, 733 P.J., Cramer, B.S., Christie-Blick, N., Pekar, S.F., 2005. The Phanerozoic record of global sea734 level change. Science 310, 1,293-1,298.

735 Miller, K.G., Mountain, G.S., Wright, J.D., Browning, J.V., 2011. A 180-million-year record of sea 736 level and ice volume variations from continental margin and deep-sea isotopic records. 737 Oceanography $24,40-53$.

738 Odin, G.S., 1982. Interlaboratory standards for dating purposes. In: Odin, G.S. (Ed.), Numerical 
Dating in Stratigraphy. John Wiley and Sons, Chichester, pp. 123-150.

740

741

742

743

744

745

746

747

748

749

750

751

752

753

754

755

756

757

758

759

760

761

Pim, J., Watts, A.B., Grevemeyer, I., Krabbenhoeft, A., 2008. Crustal structure and origin of the Cape Verde Rise. Earth Planet. Sci. Lett. 272, 422-428.

Porebski, S. \& Gradzinski, R., 1990. Lava-fed Gilbert-type delta in the Polonez Cove Formation (Lower Oligocene), King George Island, West Antarctica. In A. Colella, \& D. Prior (Eds.), Coarse Grained Deltas (vol. 10). International Association of Sedimentologists Special Publication (pp. 335-351).

Quidelleur, X., Hildenbrand, A., Samper, A., 2008. Causal link between Quaternary paleoclimatic changes and volcanic islands evolution. Geophysical Research Letters 35, L02303.

Rackzek, I., Stoll, B., Hofmann, A. W., Jochum, K.P., 2001. High-precision trace element data for the USGS reference materials BCR-1, BCR-2, BHVO-1, BHVO-2, AGV-1, AGV-2, DTS-1, DTS-2, GSP-1 and GSP-2 by ID-TIMS and MIC-SSMS. Geostandards Newsletter 25, 77-86.

Ramalho, R.S., Helffrich, G., Cosca, M., Vance, D., Hoffmann, D., Schmidt, D.N., 2010a. Vertical movements of ocean island volcanoes: Insights from a stationary plate environment. Mar. Geol. $275,84-95$.

Ramalho, R., Helffrich, G., Cosca, M, Vance, D., Hoffmann, D., Schmidt, D.N., 2010b. Episodic swell growth inferred from variable uplift of the Cape Verde hotspot islands. Nat. Geosc. 3, 774777.

Ramalho, R., Helffrich, G., Schmidt, D. N. \& Vance, D., 2010c. Tracers of uplift and subsidence in the Cape Verde Archipelago. J. Geol. Soc. Lond. 167, 519-538.

Ramalho, R. S., Quartau, R., Trenhaile, A. S., Mitchell, N. C., Woodroffe, C. D. \& Avila, S. P. (2013). Coastal evolution on volcanic oceanic islands: a complex interplay between volcanism, erosion, sedimentation, sealevel change and biogenic production. Earth-Science Reviews, 127 
140-170.

763

764

765

766

767

768

769

770

771

772

773

774

775

776

777

778

779

780

Ribeiro, L.P., Martins, S., Hildenbrand, A., Madureira, P., Mata, J., 2017. The genetic link between the Azores Archipelago and the Southern Azores Seamount Chain (SASC): The elemental, isotopic and chronological evidences. Lithos 294, 133-146.

Ricci, J., Quidelleur, X., Lahitte, P., 2015. Volcanic evolution of central Basse-Terre Island revisited on the basis of new geochronology and geomorphology data. Bull. Volcanol. 77, 84, DOI: $10.1007 / \mathrm{s} 00445-015-0970-7$.

Ricci, J., Quidelleur, X., Pallares, C., Lahitte, P., 2017. High-resolution K-Ar dating of a complex magmatic system: The example of Basse-Terre Island (French West Indies). J. Volcanol. Geotherm. Res. 345, 142-160.

Robertson, E.C., 1988. Thermal properties of rocks. USGS Open-File Report 88-441, Reston, VA, $110 \mathrm{pp}$.

Salvany, T., Lahitte, P., Nativel, P., Gillot, P.-Y., 2012. Geomorphic evolution of the Piton des Neiges volcano (Réunion Island, Indian Ocean): competition between volcanic construction and erosion since 1.4 Ma. Geomorphology 136, 132-147.

Serralheiro A., 1976. A Geologia da ilha de Santiago (Cabo Verde). Bol. Museu Lab. Mineral. Geol. Fac. Ciências Lisboa 14.

Sibrant, A., Marques, FO., Hildenbrand, A., 2014. Construction and destruction of a volcanic island developed inside an oceanic rift: Graciosa Island, Terceira Rift, Azores". J. Volcanol. Geotherm. Res. 284, 32-45.

Sibrant, A.L.R., Hildenbrand, A., Marques, FO., Weiss, B., Boulesteix, T., Hübscher, C., Lüdmann, T., Costa, A.C.G., Catalão, J.C., 2015. Morpho-structural evolution of a volcanic island developed inside an active oceanic rift: S. Miguel Island (Terceira Rift, Azores). J. Volcanol. 
Geotherm. Res. 301, 90-106.

Sibrant, A.L.R., Hildenbrand, A., Marques, F.O., Costa, A.C.G., 2015. Volcano-tectonic evolution of the Santa Maria Island (Azores): Implications for paleostress evolution at the western Eurasia-Nubia plate boundary. J. Volcanol. Geotherm. Res. 291, 49-62.

Silva, P.F., Henry, B., Marques, F.O., Hildenbrand, A., Madureira, P., Mériaux, C.A., Kratinová, Z., 2012. Palaeomagnetic study of a subaerial volcanic ridge (São Jorge Island, Azores) for the past 1.3 Myr: evidence for the Cobb Mountain Subchron, volcano flank instability and tectonomagmatic implications. Geophysical Journal International 188, 959-978.

Silva, P.F., Henry, B., Marques, F.O., Hildenbrand, A., Lopes, A., Madureira, P., Madeira, J., Nunes, J.C., Roxerová, Z., 2018. Volcano-tectonic evolution of a linear volcanic ridge (PicoFaial Ridge, Azores Triple Junction) assessed by paleomagnetic studies. J. Volcanol. Geotherm. Res. 352, 78-91.

Steiger, R.H., Jager, E., 1977. Subcommission on geochronology: convention on the use of decay constants in geo and cosmochronology. Earth Planet. Sci. Lett. 36, 359-362.

Schwarz, W.H., Trieloff, M., 2007. Intercalibration of 40Ar-39Ar age standards NL-25, HB3gr hornblende, GA1550, SB-3, HD-B1 biotite and BMus/2 muscovite. Chemical Geology 242, 218-231.

Vinnik, L., Silveira, G., Kiselev, S., Farra, V., Weber, M., Stutzmann, E., Month, 2012. Cape Verde hotspot from the upper crust to the top of the lower mantle. Earth Planet. Sci. Lett. 319-320, 259-268. https://doi.org/10.1016/j.eps1.2011.12.017.

Wilson, D., Peirce, C., Watts, A., Grevemeyer, I., Krabbenhöft, A., 2010. Uplift at lithospheric swells I: seismic and gravity constraints on the crust and uppermost mantle structure of the cape verde mid-plate swell. Geophys. J. Int. 182, 531-550. https://doi.org/10.1111/j.1365- 
809 Wilson, D., Peirce, C., Watts, A., Grevemeyer, I., 2013. Uplift at lithospheric swells II: is the Cape 810 Verde mid-plate swell supported by a lithosphere of varying mechanical strength? Geophys. J. 811 Int. 193, 798-819. https://doi.org/10.1093/gji/ggt034. 